\title{
Looking for Trouble: Framing and the Dignitary Interest in the Law of Self-Defense
}

\author{
MARGARET RAYMOND* \\ TABLE OF CONTENTS
}

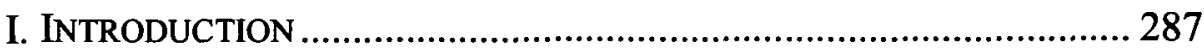

II. THE PROBLEM OF FrAMING ................................................... 289

III. THE LAW OF SELF-DEFENSE AND THE PROBLEM OF FRAMING..... 292

A. When Doctrine Looks Backwards ......................................... 293

B. The Traditional Understanding: No Expanded Frames Allowed

C. Why It Matters: Framing as Outcome Determinative.............. 299

D. Inviting the Expanded Frame: Necessity and Other

Ambiguities ............................................................................... 300

1. "Without Fault," and Other Vague Framing Formulations 308

2. Applying the Formulation in the Real World Caselaw......... 311

E. Framing Consistency and Equity Concerns ........................... 317

IV. SOLVING THE FRAMING DILEMMA: REJECTING THE BROAD

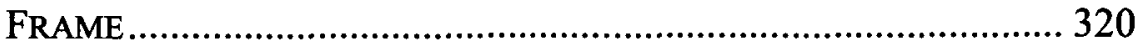

A. Valuing the Dignitary Interest ............................................ 322

B. Law Enforcement as an Inadequate Substitute ........................ 331

C. Asymmetry Between Conduct and Result ............................... 333

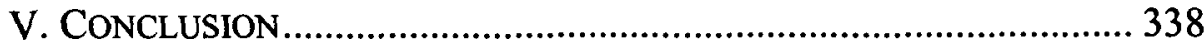

\section{INTRODUCTION}

Imagine that you are assaulted by a person threatening you with deadly force. May you lawfully respond, in turn, with deadly force? You don't yet know enough facts to determine the legality of the use of lethal force, so the answer is "it depends." If the person threatening you with deadly force is a police officer, and you are fleeing after committing a violent felony, the answer is undoubtedly no; if you are an innocent victim and the assailant intends to rob you at gunpoint, the answer is probably yes. Facts provide the

\footnotetext{
* Professor of Law, University of Iowa College of Law. Thanks to David Baldus and Eugene Volokh and to participants in the University of Miami School of Law Faculty Workshop and the Iowa Legal Theory Workshop and attendees at the Law and Society Association Annual Meeting for comments and suggestions on an earlier draft. Thanks also to Allen Best, Lindsey Karls, Benton Page, Nora Tauke, Anna Timmerman, and Julian West for able research assistance.
} 
frame that contextualizes an event and helps us understand the justice of the legal rules that apply to it.

Suppose, once again, that you are assaulted by a person threatening you with deadly force. But, looking further back in time, imagine that you wound up in that situation because you chose to enter into, rather than avoid, a potentially risky situation. Imagine, for example, that a friend told you that the assailant, a longtime enemy, was looking for you, had a gun, and planned to spend the evening at a local club. You replied, "Who cares? I'm not afraid of him. If he tries to start something with me, he'll be sorry," and headed off to the very same club. Once there, the assailant threatened you with lethal force. May you respond with lethal force in self-defense?

Some might say that, by going to the club where you knew the assailant might be, you were "looking for trouble." Should that affect whether you can claim self-defense? Should legal analysis of a self-defense situation permit consideration of an expanded time frame, in which the prior conduct of the actors may preclude their right to act in self-defense? Or should the question about the legal justification of an act of self-defense turn on the narrow circumstances of the ultimate violent interaction, without an inquiry into whether prior behavior by the actor claiming self-defense precipitated a confrontation that could have been avoided? In other words, how should we "frame" the incident in which an actor claims the right to act violently in self-defense?

One might think that the answer to this question would be clear: either the law should draw the frame broadly, to include those facts, or draw it narrowly, to exclude them. Most commentators seem to think that the law is clear on this issue. As it turns out, however, the law is decidedly ambiguous about this problem. This lack of clarity has far-reaching implications. The problem of framing an incident of the use of force in self-defense is ubiquitous; any time we consider whether a person properly used force in self-defense, we must decide how far back, both in time and circumstance, we will look to consider how the actor came to be in the situation in which force became necessary.

The problem fits into a broader analysis of what Prof. Mark Kelman has called "time-framing"l in the substantive criminal law. Prof. Kelman terms this an "unconscious interpretive construct," a way of shaping how the law views an incident that decisionmakers do not articulate, describe, or justify. ${ }^{2}$

1 Mark Kelman, Interpretive Construction in the Substantive Criminal Law, 33 StaN. L. REV. 591, 593-94 (1980-81). For a short paper by Prof. Kelman advancing these arguments and a series of responsive comments, including one by the author, see Mark Kelman, Interpretive Construction in the Substantive Criminal Law, in CRIMINAL Law CONVERSATIONS 207, 207-27 (Paul H. Robinson, Stephen P. Garvey \& Kimberly Kessler Ferzan eds., 2009).

${ }^{2}$ Kelman, supra note 1, at 593-94. 
Prof. Kelman's analysis of the general problem of time-framing invited further analysis of the issue in the context of a range of different doctrinal areas. This Article focuses on the problem in the context of the law of selfdefense.

Research suggests that the framing of a decision can have significant effects on that decision. In the criminal law context, there may not be a straightforward relationship between the choice of the frame and the likely outcome. But the decision about the framing convention that we choose will inevitably affect to a considerable degree the final result. In light of this, the law should address this problem.

This Article concludes that the law of self-defense should not permit expanding the frame in order to deny a claim of self-defense to a person based on prior decisions to engage in lawful conduct that resulted in a violent encounter. First, the Article sets out the framing issue, and demonstrates that the law as to whether the frame may be expanded to deprive an actor of a claim of self-defense is confused and unclear. In some circumstances, the law permits the expansion of the frame to deny an actor, threatened with violence, an otherwise viable claim of self-defense. The Article then argues that the law should not expand the frame to deprive an actor of a claim of self-defense. Such an expansion permits interference with the actor's dignitary interest-her freedom to move about freely and to choose where to go and what to do. It impermissibly permits aggressors to direct the behavior of others, requiring their victims to avoid confrontations in order to preserve their right of self-defense. It does so in circumstances in which law enforcement is unlikely to play a significant role in protecting the actor from the aggressor. Last of all, the expansion of the frame essentially denies a justification defense to an actor whose earlier decisions may have been made with no culpable mental state.

\section{THE PROBLEM OF FRAMING}

What do we mean by "framing" the self-defense inquiry? A decision's frame is the "conception of the acts, outcomes, and contingencies associated with a particular choice." 3 As it turns out, how we describe a decision-what we associate with it and what we treat as irrelevant to it-winds up being significant to how the decision is made. ${ }^{4}$

This is evident from research conducted by cognitive psychologists in the context of probabilistic decisionmaking. Decisionmakers express differing views about choices that are substantively identical when they are framed

${ }^{3}$ Amos Tversky \& Daniel Kahneman, The Framing of Decisions and the Psychology of Choice, 211 SCIENCE 453, 453 (1981).

${ }^{4}$ Id. 
differently. ${ }^{5}$ For example, if a choice is framed as an opportunity to save lives, decisionmakers opt for that choice more often than another, probabilistically identical choice framed in terms of the number of lives lost rather than saved. ${ }^{6}$ Students of tax policy are more amenable to a tax exemption for persons with children rather than a tax premium for childless persons, even though the net result in terms of the tax law is identical. ${ }^{7}$

What this tells us more generally is that the framing of a choice affects the choice; changes in the way an alternative is presented can make the decisionmaker more or less likely to choose that alternative. ${ }^{8}$ This is true even if the alternatives are, as an objective matter, indistinguishable from one another. These effects can be significant; "seemingly inconsequential changes in the formulation of choice problems cause[] significant shifts of preference."9 Prospect theorists would call the time-framing issue a problem of "intertemporal conflict," and recognize that differing temporal perspectives may affect the decisionmaker's choice. ${ }^{10}$

Framing effects need not be purposeful; they can "occur fortuitously, without anyone being aware of the impact of the frame on the ultimate decision." 11 But because people tend "to evaluate options in relation to the

${ }^{5}$ Amos Tversky \& Daniel Kahneman, Rational Choice and the Framing of Decisions, 59 J. Bus. S251, S261 (1986).

${ }^{6} \mathrm{Id}$. at $\mathrm{S} 260$.

${ }^{7}$ Id. at S261. For a more nuanced set of data exploring the treatment of bonuses versus surcharges in a tax scheme, see Edward J. McCaffery \& Jonathan Baron, Framing and Taxation: Evaluation of Tax Policies Involving Household Composition, $25 \mathrm{~J}$. ECON. PSYCHOL. 679 (2004).

${ }^{8}$ This is referred to as the "failure of invariance." See Daniel Kahneman \& Amos Tversky, Choices, Values, and Frames, 39 AM. PsYCHOL. 341, 343 (1984). Invariance is the principle that a rational actor, presented with a decision, would make the same choice regardless of the way in which the decision is presented. Id. The fact that this is not the case suggests that the invariance assumption is incorrect and therefore that decisionmakers are not entirely rational actors. Id. at 343-44. Trial lawyers intuitively understand this; portraying an interaction between business people as Joe's breach of a complex contractual provision is less compelling than describing it as a situation in which Sam relied on Joe's handshake and Joe broke his word.

${ }^{9}$ Tversky \& Kahneman, supra note 3, at 457 ("Individuals who face a decision problem and have a definite preference (i) might have a different preference in a different framing of the same problem, [and] (ii) are normally unaware of alternative frames and of their potential effects on the relative attractiveness of options ....").

10 Id.

11 Kahneman \& Tversky, supra note 8, at 346. They can, of course, "also be exploited deliberately to manipulate the relative attractiveness of options." Id. For example, "lobbyists for the credit card industry insisted that any price difference between cash and credit purchases be labeled a cash discount rather than a credit card surcharge." Id. 
reference point that is suggested or implied by the statement of the problem,"12 how we articulate the self-defense question goes a long way towards determining how it will be answered. ${ }^{13}$ Specifically, whether particular events are viewed as linked or not affects the decisions that are made about them. ${ }^{14}$ If we suggest to a decisionmaker that an actor's earlier choices should be linked to later events, the decisionmaker may be more likely to think they should be. ${ }^{15}$

From this, we can see that the way in which the self-defense problem is framed-whether broadly, to connect it to prior decisions and choices, or narrowly, to include only events immediately preceding the use of force for which self-defense is claimed-may have a significant effect on the decisionmaker's view of the question. Given the importance of the framing choice, the legal system should make conscious decisions about how these inquiries should be framed; "[w]hen framing influences the experience of consequences, the adoption of a decision frame is an ethically significant act." 16

Two constraints on the usefulness of the framing literature to the framing problem in self-defense are worth mentioning. First, in the experimental context, framing typically creates false distinctions between alternatives that are identical as a statistical or probabilistic matter-what one author describes as an "equivalency framing effect." 17 In the self-defense context, by contrast, the choice of frame may create substantively distinct alternatives. This context creates more of an "emphasis framing effect,"18 in

\section{$12 \mathrm{Id}$.}

13 See, e.g., Arlette Grabczynska \& Kimberly Kessler Ferzan, Justifying Killing in Self-Defence, 99 J. CRIM. LAW \& CRIMINOLOGY 235, 249 (2009) (reviewing FIONA LEVERICK, KILLING IN SELF-DEFENSE (2006)) (arguing that people's reactions to innocent aggressor hypotheticals "are subject to framing bias. The hypotheticals are presented in such a way that one imagines that one is at the bottom of the well or stuck in the elevator with the psychotic aggressor. But if we truly want to imagine the innocence and lack of conduct on the threat's part, then we must ask the question from the perspective of the threat as well." (footnotes omitted)).

${ }^{14}$ See Kahneman \& Tversky, supra note 8, at 347-48. For example, when subjects were asked whether they would buy another $\$ 10$ theater ticket to see a play if they had purchased and lost the original $\$ 10$ ticket, $54 \%$ indicated that they would not. Id. $88 \%$ of the same subjects said that they would buy a $\$ 10$ ticket to see a play even if they had lost $\$ 10$ that day. Id. The difference, the researchers posited, was what they termed "the topical organization of mental accounts." Id.

15 See id.

16 Tversky \& Kahneman, supra note 3, at 458.

17 James N. Druckman, The Implications of Framing Effects for Citizen Competence, 23 POL. BEHAV. 225, 228 (2002).

$18 \mathrm{Id}$. at 230. 
which emphasizing a particular set of facts or interests may cause a decisionmaker to focus on those facts to the exclusion of others. While the framing effects in the self-defense context will not reflect irrational distinctions between indistinguishable choices, they are, nonetheless, subject to manipulation. ${ }^{19}$ Emphasis framing effects are more significant if only one frame is offered; 20 in the context of legal decisionmaking, a factfinder may be told which frame is appropriate, creating little competition between alternative framing narratives.

Second, in the context of straightforward probabilistic decisions, the way the question is framed can produce identifiable and predictable categories of bias. Decisionmakers opt for choices termed risk-averse rather than riskseeking; for example, they prefer to bestow benefits rather than impose penalties, and they prefer the status quo. In the context of self-defense, by contrast, the framing decision may not consistently bias the decisionmaker in a predictable and reproducible direction. ${ }^{21}$

The way the self-defense issue is framed will affect the decisionmaker, but there is still a normative choice to be made about which framing choice is correct. The next section demonstrates that the law is inconsistent and uncertain about this important substantive question.

\section{The LaW of Self-Defense AND the Problem of Framing}

The classic description of self-defense treats as justified the use of reasonable, proportionate and necessary force in response to an imminent threat of unlawful force. As described by Prof. LaFave:

One who is not the aggressor in an encounter is justified in using a reasonable amount of force against his adversary when he reasonably believes (a) that he is in immediate danger of unlawful bodily harm from his adversary and (b) that the use of such force is necessary to avoid this danger. ${ }^{22}$

Deadly force is typically permitted only if the actor "reasonably believes that the other is about to inflict unlawful death or serious bodily harm upon him (and also that it is necessary to use deadly force to prevent it)." ${ }^{23}$ Framing is

19 Id. at 235.

$20 \mathrm{Id}$. at 244.

21 See infra notes 60-61 and accompanying text.

22 WAYNE R. LAFAVE, SubSTANTIVE CRIMINAL LAW $§ 10.4$ (2d ed. 2003).

$23 \mathrm{Id}$. at 145 . Jurisdictions requiring retreat typically require it only before the use of deadly force. See id. at 155; see also JOSHUA DRESSLER, UNDERSTANDING CRIMINAL LAw $\S 18.01[\mathrm{~B}]$ (5th ed. 2009) ("[D]eadly force is only justified in self-protection if the actor 
an issue in any self-defense case, but, as will become apparent, it presents a significant legal issue in cases involving lethal self-defense.

Because self-defense is a justification, where the elements of self-defense are satisfied, the actor who committed the intentional but justified harm is guilty of no crime. ${ }^{24}$ Legal rules that permit or prohibit the assertion of a selfdefense claim accordingly control the outcomes of cases in which they are applied.

The law as it is articulated above seems to envision as relevant only the immediate encounter between the actors in which the challenged force is used. That, as it turns out, is an oversimplification. Under some circumstances, the law opens the door to a more generalized inquiry into whether the actor claiming self-defense is somehow to blame for the situation in which he needed to use force-whether he was "looking for trouble"--and whether that should deprive him of the right to claim self-defense for what would otherwise be the lawful use of force.

This expanded frame is the subject of this Article. It is not, however, the only instance in which self-defense law looks backward in time to events that preceded the ultimate violent encounter. The following section discusses these other instances briefly.

\section{A. When Doctrine Looks Backward}

Self-defense doctrine looks backward, in part, to address the complexities that reality imposes on the pristine law of self-defense. Selfdefense cases rarely reflect what one author describes as the "paradigm of self-defense"25 _ "the violator of peace versus the law-abiding citizen, or, more simply, antagonist versus protagonist, villain versus hero."26 Selfdefense situations are often more complex and ambiguous, involving an escalation of provocative, aggressive, and unlawful behavior on the part of both participants in an altercation. ${ }^{27}$ This means that the privilege of selfdefense can belong to and be lost repeatedly by each of the participants in a violent encounter-a dance of shifting privileges, in which each actor can in

reasonably believes that its use is necessary to prevent imminent and unlawful use of deadly force by the aggressor.").

${ }^{24}$ LAFAVE, supra note $22, \S 10.4$ (a).

25 See Janine Young Kim, The Rhetoric of Self-Defense, 13 BERKELEY J. CRIM. L. 261, 265-66 (2008) ("[T]he sudden assault by a murderous stranger, such as when someone, perhaps bent on robbery, comes out of a dark alley with a gun and threatens to kill a person walking innocently down the street." (quoting CYNTHIA K. GILLESPIE, JUSTIFIABLE HOMICIDE 4 (1989))).

${ }^{26} \mathrm{Kim}$, supra note 25 , at 266.

27 Prof. Kim, too, recognizes this, noting that the traditional paradigm "is a scene that blinds us to the unresolved uncertainties of self-defense." $I d$. at 268. 
turn acquire and lose the right to respond with force to unlawful force exerted against him. To untangle these difficulties, the law identifies some simplifying rules which require inquiry not simply into who struck the final blow, but into what took place before that.

One such rule denies the privilege of self-defense to an initial aggressor. ${ }^{28}$ For the initial aggressor to regain the privilege of using deadly force, she must communicate her intention to withdraw from the violent encounter fairly to the other actor. Accordingly, a self-defense case requires looking back in time to determine whether the person claiming self-defense was the person who started the altercation, and, if so, whether that person withdrew unequivocally from the encounter.

Another inquiry that may require an analysis of events preceding the final violent interaction turns on the fact that, to be justified, self-defense can only be used in response to the threat of unlawful force. In a violent encounter, determining whether the use of force by one actor is justified, and therefore lawful, requires analysis of each escalation of force to determine whether the force used was disproportionate and therefore unlawful.

Imagine, for example, that $\mathrm{Al}$ and $\mathrm{Bob}$ are at a bar. Bob speaks to $\mathrm{Al}$ in a way that $\mathrm{Al}$ perceives as disrespectful, and $\mathrm{Al}$ takes offense. Al, a diminutive man in his sixties, takes a swing at Bob, a tall and strong 35-year-old, in an attempt to punch him in the stomach. Bob avoids the blow without difficulty, and responds by punching Al full-force in the face. Al falls to the ground, his nose broken, and strikes his head on the concrete pavement. Al pulls out a switchblade knife. Whether Bob may respond to Al's threatened use of lethal force with lethal force may depend in part on whether his striking $\mathrm{Al}$ constituted a proportionate (and therefore lawful) use of force. ${ }^{29}$

Another element that requires an inquiry into the events preceding the final encounter is the requirement, in some jurisdictions, that the actor, in order to claim self-defense, must not have "provoked" the conflict. ${ }^{30}$ Some

28 See LAFAVE, supra note $22, \S 10.4$ (e) ("It is generally said that one who is the aggressor in an encounter with another-i.e., one who brings about the difficulty with the other-may not avail himself of the defense of self-defense." (footnote omitted)). Prof. LaFave assumes that "bringing about the difficulty" means being the initial aggressor, but it is not clear that the term is understood so narrowly. See infra notes 108-09 and accompanying text.

29 If so, Al would not be privileged to respond to that lawful use of force with lethal force, and so Al's use of force would be unlawful, entitling Bob to use lethal force in self-defense.

${ }^{30}$ In some jurisdictions, the actor loses his privilege of self-defense only if he provokes the incident with the intent to cause death or serious bodily injury. See, e.g., Jeanne E. Neese, Criminal Procedure-Provocation Not a Bar to Self-Defense in Absence of Intent to Cause Death or Serious Bodily Injury-Commonwealth v. Samuel, 590 A.2d 1245 (Pa. 1991), 65 TEMP. L. REV. 751, 751 (1992) (discussing a case in which 
jurisdictions have broad instructions relating to the issue of provocation, asking, for example, whether the defendant "provoked or incited the use of force against (himself/herself) in the same encounter," 31 "provoked another with the intent to cause the altercation," 32 or "provoked the [deceased's] . . [use] ... of unlawful force. ..."33

Several issues relevant to a claim of self-defense accordingly require looking backward to consider the facts that led up to the ultimate violent encounter. In these situations, however, the inquiry into the past is designed to ask a distinct, clearly articulated question. The issue this Article addresses is whether the factfinder can expand the frame to invite a broader and more diffuse inquiry: whether the actor should have done something to avoid the situation in which he found himself, and whether that failure should act as a bar to a subsequent claim of self-defense.

One might think that this obvious framing problem would be clearly identified and clearly addressed by both legislatures and scholars in the area of self-defense. As it turns out, that is not the case.

\section{B. The Traditional Understanding: No Expanded Frames Allowed}

Contemporary self-defense law is distinctly unclear about how decisionmakers should frame the encounter in which they assess the legitimacy of a self-defense claim. ${ }^{34}$ This is not, however, the view of many commentators, who express the mistaken belief that the law is clear and precludes expanding the frame.

This understanding of self-defense law comes largely from an expansive range of early cases and authorities, many dating from the late nineteenth or

a state supreme court required a state to prove "that a defendant intended to cause death or serious bodily injury to negate the claim of self-defense on the basis of provocation in homicide cases"). Other provocation instructions limit the provocation exception to situations in which the victim was the initial aggressor, but the defendant intentionally brought on the difficulty "for the purpose and with the intent that the defendant would have a pretext for killing the victim." Smith v. State, 965 S.W.2d 509, 518 (Tex. Crim. App. 1998).

31 N.J. MODEL CRIM. JURY CHARGES, N.J.S.A. § 2C:3-4 (2000).

32 OKLA. UNIF. JURY INSTRUCTIONS-CRIM. $\$ 8-50$ (2006).

33 TENN. PATTERN JURY INSTRUCTIONS-CRIM. \$ 40.06 (2006).

${ }^{34}$ Framing is relevant to any claim of necessity. Consider, for example, a claim of police use of force. If the applicable legal rule is that the use of force is justified where it is "necessary," a dispute about a use of force incident might turn on at what point that necessity should be assessed. The officer might suggest that at the point at which he used force, he was threatened by a violent individual and that the use of force was therefore "necessary," while the state might assert that certain acts taken by the officer before the encounter turned violent exacerbated the situation and generated the need for the use of force. 
early twentieth centuries, in which courts held that a defendant could not be denied a claim of self-defense based on his prior lawful decisions and choices. These cases, reflecting a decided flavor of the frontier, focused on the importance of preserving the individual's right to freedom of action. ${ }^{35}$ They firmly stated the principle that one lawfully minding his own business need not alter his behavior-even in the face of the anticipated aggression of another-in order to claim self-defense. Courts routinely reversed cases in which instructions required the defendant to have acted affirmatively to avoid the entire difficulty. It was error, held one, to instruct the jury that defendant's

right of self-defense did not arise until he had 'done everything in his power to avoid the necessity' of slaying his adversary. He might have avoided such necessity by secreting himself so that he could not be found, or by abandoning his home and seeking safety in some remote part of the country; but under the law he was not required to resort to either of these methods of securing his personal safety. ${ }^{36}$

One court vehemently rejected an instruction that suggested that by arming himself and going to where the victim was, the defendant provoked the attack and could not claim complete self-defense:

Defendant's presence at the place where the killing occurred could not, under the circumstances, constitute provocation to the deceased. Defendant had the right to be at that place. It was a public street, and at the entrance to the house in which he did business. It was his daily habit to be at the place going to and from his work.... There was nothing wrong-nothing unusual or strange-in his presence at the place on the occasion of the killing. With what reason, then, can it be claimed that his presence at the place provoked, or was calculated to provoke, the deceased to attack him $?^{37}$

${ }^{35} \mathrm{Kim}$, supra note 25 , at 266-67 ("[C]ountering unjust violence with just violence evokes romanticized images of the cowboy or adventurer, defending himself (and perhaps also his honor) against the perils of the lawless frontier.").

36 Bohannon v. Commonwealth, $71 \mathrm{Ky}$. (8 Bush) 481, 486 (1871).

37 Ball v. State, 14 S.W. 1012, 1013 (Tex. Ct. App. 1890); see also Cheney v. State, 55 So. 801, 802-03 (Ala. 1911), holding it was error not to instruct the jury that:

[i]n going to his poolroom the defendant could not be considered as at fault in bringing on the difficulty. The defendant had the right to go to his place of business without being placed at fault in bringing on the difficulty.... [T] slightest proof that he provoked the deceased at the time of the homicide, ... other than by merely appearing in his own place of business where he had the right to go.).

See also People v. Gonzales, 12 P. 783, 787 (Cal. 1887): 
The classic statement of the notion that an actor need not avoid an encounter to be entitled to claim self-defense was articulated in State $v$. Gardner:

[A] person knowing his life to be threatened, and believing himself to be in danger of death or great bodily harm, is not obliged to remain at home in order to avoid an assault, but may arm himself sufficiently to repel anticipated attack, and pursue his legitimate avocation; and if without fault, he is compelled to take life to save himself, he may use any weapon he may have secured for that purpose, and the homicide is excusable. ${ }^{38}$

Even where courts did not expressly articulate this principle, they rejected any notion that the frame should be expanded to ask whether a defendant claiming self-defense should have engaged in alternative avoidance behaviors earlier in the encounter ${ }^{39}$ In State v. Adler, for example, Adler and Johnson got into an altercation. ${ }^{40}$ Adler "retreated, and ran into a grocery store," but "remained in the store but a very short time."41 When he returned to the street, he had a revolver in his hand ${ }^{42}$ Outside the store was a mob of about two hundred people. ${ }^{43}$ The court concluded that Adler, by entering the store, had abandoned the conflict, and was therefore entitled to defend himself when he emerged from the store. ${ }^{44}$ The court did not suggest that Adler was obliged to choose an alternative course of conduct-such as

[O]ne may know that if he travels along a certain highway be [sic] will be attacked by another with a deadly weapon, and be compelled in self-defense to kill his assailant, and yet he has the right to travel that highway, and is not compelled to turn out of his way to avoid the expected unlawful attack.

See also State v. Evans, 28 S.W. 8, 11 (Mo. 1894):

If the mere expectation of an assault from an adversary is to deprive the expectant of the right of self-defense, merely because he goes armed in the vicinity of his enemy, or goes out prepared upon the highway where he is likely at any moment to meet him, then he has armed himself in vain, and self-defense ceases wherever expectation begins. We do not so understand the law.

38 State v. Gardner, 104 N.W. 971, 975 (Minn. 1905); see also State v. Jackson, 382 P.2d 229, 232 (Ariz. 1963) ("On [sic] who merely does an act which affords an opportunity for conflict is not thereby precluded from claiming self-defense.").

${ }^{39}$ E.g., State v. Adler, 47 S.W. 794, 794-95 (Mo. 1898).

${ }^{40} \mathrm{Id}$.

41 Id. at 795.

42 Id.

43 Id.

${ }^{44}$ Id. at 796. 
staying in the store-that would have enabled him to avoid his assailant as well as the rest of the angry mob. ${ }^{45}$

More contemporary authorities, relying largely on these earlier pronouncements, seem equally assured in their view that self-defense law does not endorse a broad framing inquiry that looks into the history of the altercation and imposes on the actor claiming self-defense the obligation to avoid it. ${ }^{46}$ Wrote one, "[A] rule that demands the defendant "avoid the confrontation' ... has never been part of standard self-defense law. There is no general duty to avoid violence before the confrontation."47 These authorities, for the most part, ground this understanding squarely in the principle of freedom of movement: that the law of self-defense does not interfere with the privilege of the actor to go where he chooses. ${ }^{48}$

The problem with the certainty of these commentators about the framing issue is that the law is, in fact, decidedly unclear about which of these diametrically opposite approaches —one that looks back in time to the actor's

45 In State v. Bristol, 84 P.2d 765, 765-67 (Wyo. 1938), the court held it improper for the jury to conclude that the defendant was deprived of the right to self-defense even though he went to a restaurant knowing that the victim was there and had threatened her previously. The court agreed that principles like "[t]he duty to avoid a difficulty; that one who kills must not be at fault; that the right to kill is based on the law of necessity . . . are broad and general terms, and if literally applied would cover the point now before us." Id. at 762. After a lengthy analysis of authorities, the court concluded nonetheless that "neither the fact of arming himself, nor the fact of going to the restaurant, even if he knew that the deceased was there, was sufficient to deprive the defendant of the right of self-defense." Id. at 765; see also People v. Macard, 40 N.W. 784, 787 (Mich. 1888) ("The question of... whether respondent could have avoided the threatened assault ... [was] not for the jury.").

46 See, e.g., ANDrew Ashworth, PrINCIPLeS of Criminal Law 119 (1991) (no duty to avoid conflict "in those cases where $D$ is acting lawfully in remaining at, or going to, a place, realizing that there is a risk that someone will force a violent confrontation there"); see also Kim, supra note 25, at 284 ("[T] he law makes self-defense available to even gun-toting, racist vigilantes so long as the situation calls for it.").

47 V.F. Nourse, Self-Defense and Subjectivity, 68 U. CHI. L. REV. 1235, 1284 (2001):

\begin{abstract}
A retreat rule may require the defendant to withdraw once the confrontation has begun, but a rule that demands the defendant "avoid the confrontation" is an entirely different requirement; such a "pre-retreat" rule is far more severe and, indeed, has never been part of standard self-defense law. There is no general duty to avoid violence before the confrontation. The man who goes for the fiftieth time to the violent gang-bar is not deprived of his self-defense claim because he "should have left before the violence erupted.
\end{abstract}

48 See id. at 1284 ("[T]he common law of self-defense protects the freedom to move."); Rollin M. PERKINS \& Ronald N. BoyCE, CRIMINAL LAW 1131 (3d ed. 1982) ("The fact that one who has been threatened arms himself for defense does not deprive him of the normal privilege, or of his right to go about his business as usual."). 
ability to avoid the circumstances giving rise to the altercation, and one that vehemently rejects such an approach-is correct. This ambiguity reflects some uncertainty about the underlying principle, reflecting a more modern perception that one's right to go where one wishes must sometimes be subordinated to the need to preserve life.

\section{Why It Matters: Framing as Outcome-Determinative}

Before turning to the law that creates framing ambiguities, it is important to demonstrate that the choice of frame has concrete and significant consequences for the outcome of self-defense cases. This is evident from a New York case, People v. Simmons. ${ }^{49}$ Martinez, who was drunk, accosted Simmons. ${ }^{50}$ Martinez demanded money, Simmons refused, and the men exchanged words. ${ }^{51}$ As the argument escalated into a fight, Simmons suggested that the two "take it outside," where there was a fistfight, initiated by Simmons. ${ }^{52}$ Martinez then began "digging in his pants." 53 Simmons began walking away, but upon seeing that Martinez appeared to be reaching for a weapon, returned. ${ }^{54}$ Martinez pulled out his gun, and the two began struggling for it. ${ }^{55}$ Martinez began firing and shot Simmons; ultimately Simmons gained control of the weapon and shot Martinez, killing him. ${ }^{56}$ Simmons was convicted of manslaughter; the prosecutor's theory was that "the defendant could be considered criminally liable for murder because he failed to 'walk away' at the time of his initial confrontation with the decedent in the lobby." 57 The appellate court reversed; in its view, the trial court should have made clear that the critical time frame in which to assess the defendant's behavior was the point at which "the defendant actually exerted deadly physical force against the decedent...."58 This narrowly drawn frame was, in the court's view, the appropriate one; "[i]t was ... irrelevant

49615 N.Y.S.2d 56 (N.Y. App. Div. 1994).

$50 \mathrm{Id}$. at 57.

$51 \mathrm{Id}$.

$52 \mathrm{Id}$. at $57-58$.

${ }^{53} \mathrm{Id}$. at 58.

54 Id.

55 Simmons, 65 N.Y.S.2d at 58.

$56 \mathrm{Id}$.

57 Id. In closing argument, "the prosecutor argued, '[he] followed the deceased out. He provoked this fight. He went after [the decedent]. He didn't walk away when he could have. This isn't self-defense."' Id.

${ }^{58} \mathrm{Id}$. 
that the defendant might have been able to walk away at the time of the initial encounter ...."59

How we draw the frame, then, can definitively determine whether an actor may claim self-defense. The next question is whether there is a clear advantage to one party or the other in drawing the frame narrowly or broadly. Some have argued that there is a distinct directional bias in the choice of frame. Prof. Jody Armour has argued, for example, that defendants favor a broad frame that enables the factfinder to consider the narrative context of the alleged crime, while the state favors "a narrow time frame that excludes evidence about events leading up to the criminal incident." $60 \mathrm{He}$ argues that review of context and an expanded frame invariably leads to a more sympathetic view of the defendant. ${ }^{61}$ This might be true in some categories of cases; in particular, in assessing claims of self-defense made by victims of domestic violence, expanding the frame might provide a more sympathetic and more nuanced understanding of the defendant's actions. As the next section will show, however, a broad frame can also deny a defendant a selfdefense claim. The inevitable conclusion is that the framing issue is malleable and manipulable in the service of differing interests.

\section{Inviting the Expanded Frame: Necessity and Other Ambiguities}

As Section III.B demonstrated, caselaw and contemporary authorities have suggested that there is no framing problem in the context of selfdefense. This is inaccurate. Even the early caselaw was more ambiguous than the contemporary analysis suggests. Language requiring one claiming selfdefense to "employ[] all means in his power . . . to avoid the danger and avert the necessity of taking life" left the matter unclear. ${ }^{62}$ Such ambiguity has

${ }^{59}$ Id. at 59.

60 Jody Armour, Just Deserts: Narrative, Perspective, Choice, and Blame, $57 \mathrm{U}$. PITT. L. REV. 525, 526 (1995-96).

${ }^{61} \mathrm{Id}$. at $526-57$.

62 See, e.g., State v. Schroeder, 176 P. 659, 660 (Kan. 1918) ("The testimony offered by the defendant shows that he was not seeking to avoid danger or to do everything in his power to avert the necessity of shooting, as was his duty under the law."); People v. Kennedy, 54 N.E. 51,52 (N.Y. 1899) ("[W] hen one believes himself about to be attacked by another, and to receive great bodily injury, it is his duty to avoid the attack, if in his power to do so, and the right of attack for the purpose of self-defense does not arise until he has done everything in his power to avoid its necessity."); Lee v. State, 9 So. 407, 407-08 (Ala. 1891) ("' I]n order to entitle a person to the benefits of the plea of selfdefense against the charge of homicide, he must have employed all means in his power, consistent with his safety, to avoid the danger and avert the necessity of taking life ...."); Waller v. State, 8 So. 153, 155 (Ala. 1890) ("Defendant cannot contribute to 
persisted and developed further in contemporary law. One vehicle injecting such ambiguity is the requirement of "necessity."

Self-defense purports to be grounded on necessity. In theory, that means that nothing short of the necessity to exercise the use of force will justify it; if we are talking about lethal force, that means the necessity for the taking of life. Courts hesitant to sanction the taking of life as justified have sometimes interpreted the concept of necessity more expansively to preclude the claim. ${ }^{63}$

To begin with, it should be said that the notion that necessity drives selfdefense is overly simplistic. Even in the paradigmatic case of lethal selfdefense-in which an entirely innocent actor is confronted by an aggressor threatening imminent deadly force-the use of deadly force may be inevitable, but it is not, strictly speaking, necessary. ${ }^{64}$ Even leaving aside the idea that a threat to one's life might not create the necessity to take the life of another, necessity is not universally required in the application of selfdefense doctrine. As numerous authors have noted, the theoretical underpinning of the law of self-defense is by no means consistent or unilateral. ${ }^{65}$ While some components of the doctrine of lethal self-defense are premised on the notion that life must be preserved at all costs, ${ }^{66}$ deemed the

bringing on the difficulty, and voluntarily and unnecessarily placing himself in a situation of danger excuse killing his adversary on the right of self-defense.").

${ }^{63}$ See Laney v. United States, 294 F. 412,414 (D.C. Cir. 1923) ("[B]efore a person can avail himself of the plea of self-defense against the charge of homicide, he must do everything in his power, consistent with his safety, to avoid the danger and avoid the necessity of taking life.").

64 The inevitability of self-defense does not make it necessary, but it explains why we might choose not to punish it. As Prof. George Fletcher points out, we view the use of lethal force in response to a threat of death as permissible not because it is necessary, but because it is involuntary. Because most actors whose lives were threatened would save their own lives at the expense of their adversary's lives, we treat this conduct as privileged as a "way of making the moral claim that he is not to be blamed for the kind of choice that other people would make under the same circumstances." GEORGE FLETCHER, RETHINKING CRIMINAL LAW § 10.5.1 (1978); see also Boaz Sangero, A New Defense for Self-Defense, 9 BUFF. CRIM. L. REV. 475, 501 (2005-06) ("Although the . . . actor does have an (objective) choice of alternative behavior, her freedom of choice is nonetheless restricted. In the difficult situation in which the actor finds herself, the survival instinct is very powerful. This is human nature.").

65 See Nourse, supra note 47 , at 1273 (arguing that "the law's necessity is not always as 'necessary' as it may seem, if by necessary we mean that the defendant must choose the 'least violent' or 'most pacifist' alternative").

66 Catherine L. Carpenter, Of the Enemy Within, the Castle Doctrine, and SelfDefense, 86 MARQ. L. REV. 653, 676 (2003). 
"pacifist" view ${ }^{67}$ by one scholar and a type of "lesser evils" approach by another, ${ }^{68}$ others do not require a singleminded focus on the saving of lives. ${ }^{69}$ Self-defense law, derived as it is from an amalgam of theoretical perspectives, privileges necessity in some aspects but not in all.

Imminence, for example, is a product of the necessity requirement. ${ }^{70}$ Most jurisdictions require a person claiming self-defense to demonstrate that he or she faced an imminent threat of unlawful force. ${ }^{71}$ In theory, a person who faces a non-imminent threat of death or serious bodily injury does not need to act in self-defense. First, it is possible that the threat may never come to pass; a mere threat of future violence may not be acted upon, and therefore does not create a genuine necessity. ${ }^{72}$ Second, even if the future threat is certain, the actor may have access to other solutions besides retaliatory violence, making a resort to self-defense unnecessary. ${ }^{73}$ The doctrine of proportionality can also be understood as driven by necessity. ${ }^{74}$

At the same time, the rejection of the retreat requirement in a majority of American jurisdictions ${ }^{75}$ and the adoption of the castle doctrine even where the law would otherwise require retreat reflect a focus on other concerns besides necessity. If the need to preserve life were the exclusive justification for self-defense doctrine, retreat would always be required. Someone who

${ }^{67}$ This is Prof. Nourse's terminology. See Nourse, supra note 47 , at $1271-72$. "The pacifist stresses a view of necessity that depends upon the need for the defendant to avoid violence." Id. Prof. Nourse describes the pacifist position as "almost orthodoxy." Id. at 1272.

68 This is Prof. Fletcher's view. See FLETCHER, supra note $64, \S 10.5 .2$.

69 Sanford H. Kadish, Respect for Life and Regard for Rights in the Criminal Law, 64 CAL. L. REV. 871, 879 (1976) (preservation of life principle is systematically contradicted by the criminal law).

70 Prof. Richard Rosen deems imminence a "“translator"” of the necessity principle: it is required "because, and only because, of the fear that without imminence there is no assurance that the defensive action is necessary to avoid the harm." Richard A. Rosen, On Self-Defense, Imminence, and Women Who Kill Their Batterers, 71 N.C. L. REV. 371, 380 (1993).

${ }^{71}$ For a detailed discussion of the confused way in which the concept of imminence is applied in self-defense cases, see Nourse, supra note 47.

72 See 2 Paul H. Robinson, CRiminal Law DefEnSES, § 131(c), at 77 (1984) ("The actor should not be permitted to use force when such force would be equally as effective at a later time and the actor suffers no harm or risk by waiting.").

73 See Nourse, supra note 47 , at 1276-77. As Prof. Nourse discusses, this analysis can convert the question of temporal imminence into a problem of the avoidability of the threat, which implicates other aspects of self-defense law, including the requirement (or not) of retreat.

74 See Paul H. Robinson, Criminal Law $\$ \S 8.1,8.4$ (1997).

75 LAFAVE, supra note $22, \S 10.4(\mathrm{f})$. 
could, with complete safety, avoid the need to resort to lethal force by running away from the threat has no real "need" to use that force. ${ }^{76}$ Necessity-or more correctly, its absence-is routinely articulated as the theoretical basis for the retreat rule.

The requirement of retreat is not by any means universally recognized, however. American jurisdictions have been divided as to whether retreat is required. ${ }^{77}$ In the American West, the principle of retreat was soundly rejected $7^{78}$ it seemed to require an unmanly obligation to flee a physical confrontation ${ }^{79}$ and to exacerbate the threat posed by a threatened assailant, who might be more likely to threaten unlawful force if the law required his victims to flee from him rather than confront him. ${ }^{80}$ One Oklahoma court, rejecting an instruction which required the defendant to "employ all

76 DRESSLER, supra note $23, \S 18.02[\mathrm{C}][2]$ ("If a person can safely retreat and, therefore, avoid killing the aggressor, deadly force is, objectively speaking, unnecessary."); see also Carpenter, supra note 66, at 694 ("At its core, the obligation to retreat is no more than a shorthand way to underscore the importance of necessity in the use of deadly force.").

${ }^{77}$ Carpenter, supra note 66, at 655.

78 See David W. Collins, The Duty to Retreat, 3 CRIM. JUST. Q. 80, 82 (1975) ("[W]ith westward expansion a dichotomy began to appear. Some states continued to require a person exposed to an unprovoked, deadly assault to retreat, while others, chiefly the western and southern states, did not require retreat.").

79 See Carpenter, supra note 66, at 655 n.6 (referring to the refusal to require retreat as the "true man" doctrine); see also State v. Renner, 912 S.W.2d 701, 704 (Tenn. 1995). As one author suggested,

the American traditions of vigilantism, the competitive spirit, and especially the idea that it is cowardly to retreat, which are continually broadcast and reinforced by the mass media, can only lead to a conditioned response on the part of a victim meeting, 'at the moment of truth,' a felonious assault. In view of this conditioning, it appears both unrealistic and unreasonable to continue to require a duty to retreat by one exposed to a felonious attack.

Collins, supra note 78, at 88 (footnote omitted); see also Dan Kahan, The Secret Ambition of Deterrence, 113 HARV. L. REV. 413, 433 (1999) ("[T] he dispute over the 'true man' doctrine was about whose minds--those of the aristocratic South and the ruggedly individualistic West, on the one hand, or those of the more egalitarian and cosmopolitan East, on the other-would be proclaimed genuinely 'American' by the law.").

${ }^{80}$ See, e.g., Philips v. Commonwealth, 63 Ky. (2 Duv.) 328, 331 (1865):

[R]unning once may induce the assailant to believe that the assailed will never stand and manfully defend himself, and thus embolden him to renew his attacks without apprehension of any resistance perilous to himself. If the party once assailed by an enemy who had threatened to kill him is bound by law to run if he can thereby escape that assault, legal self-defense may become a mockery and the sacred right itself a shadow. 
reasonable means within his power, consistent with his safety, to avoid the danger and avert the necessity of the killing," 81 wrote:

This practically placed the burden upon the appellant of proving his innocence.... Under the old common law, no man could defend himself until he had retreated, and until his back was to the wall; but this is not the law in free America. Here the wall is to every man's back. It is the wall of his rights; and when he is at a place where he has a right to be, and he is unlawfully assailed, he may stand and defend himself. ${ }^{82}$

Although the Model Penal Code attempted to impose a requirement of retreat, such a requirement is still a minority rule in American criminal law. ${ }^{83}$

Even where it applies, the retreat requirement has its limitations. First, there are places-most often the home, under the so-called "castle doctrine"-where the threatened actor is not obliged to retreat. ${ }^{84}$ Moreover, the requirement of retreat is ordinarily limited to situations in which retreat can be effected without risk to the actor; this condition of perfect safety radically limits the application of the retreat requirement, particularly in the context of modern weaponry. ${ }^{85}$ We might expect a theory of self-defense premised on the importance of saving lives at all costs to be considerably

81 Fowler v. State, 126 P. 831,833 (Okla. Crim. App. 1912).

82 Id.

${ }^{83}$ Model Penal CODE $§ 3.04(2)$ (b); LAFAVE, supra note $22, \S 10.4(\mathrm{f})$. The attempt to bring in retreat through a more generalized inquiry into the "reasonableness" of the actor's conduct is discussed infra notes $140-49$ and accompanying text.

84 The problems this creates when both actors are residents of the home, and the implications for self-defense claims asserted by battered spouses, are discussed in Carpenter, supra note 66 . The Model Penal Code accepts this limitation on the duty to retreat. See MOdel PENAL CODE § 3.04(2)(b)(ii)(2).

85 The Model Penal Code requires retreat only where "the actor knows that he can avoid the necessity of using such force with complete safety by retreating." MODEL PENAL CODE $\$ 3.04(2)$ (b)(ii). A person faced with a threat of gunfire can rarely avoid the situation with complete safety simply by retreating. See Laney v. United States, 294 F. 412, 414-15 (D.C. Cir. 1923):

[T] he common-law rule, which required the assailed to retreat to the wall, had its origin before the general introduction of firearms. If a person is threatened with death or great bodily harm by an assailant, armed with a modern rifle, in open space, away from safety, it would be ridiculous to require him to retreat. Indeed, to retreat would be to invite almost certain death.

The Minnesota Supreme Court suggested that the retreat doctrine did not make any sense when dealing with firearms. See State v. Gardner, 104 N.W. 971, 975 (Minn. 1905). 
more vigorous in its enforcement of a retreat requirement-or perhaps to have a different and more inclusive view of necessity. ${ }^{86}$

Other evidence that necessity is not the sole driving theory behind selfdefense doctrine is provided by statutes that permit lethal force to be used to resist or oppose the commission of certain categories of forcible felony ${ }^{87}$ While avoiding a forcible felony is important, it is not inevitably the case that every instance of a forcible felony poses the kind of risk to the life of the actor that necessity would require. ${ }^{88}$ Permitting the use of lethal force to prevent the crime-effectively using the threatened felony as a proxy for grave danger to the actor-will include in the scope of lawful use of lethal force in self-defense some situations in which there is no necessity for the taking of life. ${ }^{89}$

${ }^{86}$ See, e.g., Nourse, supra note 47 , at 1271 :

Those theorists, like George Fletcher, who urge that an imminence requirement is essential to a justified self-defense claim, do so based on a theory of self-defense that is heavily invested with pacifism and social responsibility toward the victim's interest in life. The idea is that a defendant's act is justified when necessary, where necessity means that the defendant had 'no' alternative but to kill. But this is not the only available view of necessity. Theories of self-defense that focus on autonomy do so on the basis that '(r)ight need never yield to wrong.' The argument is that the killing is 'necessary' when it serves to right the wrong of a deadly attack.

${ }^{87}$ For example, the New York Penal Law permits an actor to use deadly force against another person if "[h]e or she reasonably believes that such other person is committing or attempting to commit a kidnapping, forcible rape, forcible criminal sexual act or robbery." N.Y. PENAL LAW $\S 35.15(2)(b)$ (McKinney 2004). In the notorious Bernhard Goetz case, the self-defense claim was premised not on an imminent threat of the use of lethal force, but on a claim that Goetz believed that he was facing an attempted robbery. George P. Fletcher, A Crime of Self-Defense 22 (1988). As Prof. Fletcher notes, this rule-permitting the use of deadly force in response to a threat of robbery-is "more favorable than many states to claims of self-defense." Id. Other states with provisions explicitly enumerating the felonies that may be resisted with lethal force include Colorado, COLO. REV. STAT. ANN. § 18-1-704(2) (West 2009), and Nebraska, NEB. REV. STAT. $§ 28-1409$ (4) (2009). Some jurisdictions have statutes providing that deadly force is justifiable to prevent the commission of a felony, but judicial interpretations of that language have limited the use of deadly force to prevention of dangerous felonies. See, e.g., Mammano v. State, 333 P.2d 602, 605 (Okla. Crim. App. 1958); State v. Nyland, 287 P.2d 345, 347 (Wash. 1955) (holding prevention of the felony of adultery did not justify homicide).

${ }^{88}$ Kadish, supra note 69 , at 888 . Prof. Paul Robinson suggests that under such a provision, a technical violation of a kidnapping statute - carrying a bus passenger past his stop, for example - might justify the use of lethal force, even in a situation in which there was no risk to life. ROBINSON, supra note 72 , at 83-84.

${ }^{89}$ One author has proposed that battered spouse self-defense might in some circumstances be recast as claims of defense against kidnapping, to avoid some of the problems inherent in those cases. See Gregory A. Diamond, To Have But Not to Hold: 
Even if we accept the proposition that necessity governs the applicability of self-defense law, however, the framing problem remains. If the frame is drawn to include the defendant's own prior conduct and, on that basis, the ultimate use of force is deemed unnecessary, self-defense is unavailable. A frame drawn broadly to include a range of prior choices that should, in retrospect, have been made differently may result in the conclusion that the ultimate use of force was unnecessary and therefore unjustified. The frame in which we assess "necessity" is therefore critically important.

The facts of Laney $v$. United States ${ }^{90}$ provide a powerful example of the framing problem. In July of 1919 , William Laney, a black man, was on the street in Washington, D.C. when he was pursued by a large and violent white mob shouting racist epithets and threats. ${ }^{91}$ Laney, fearful for his life, pulled out a gun, which caused the mob to disperse, and ducked into an alley. ${ }^{92}$ Some time later, believing that the danger was past, he returned to the street, hoping to go to work. ${ }^{93}$ The mob resumed its pursuit of Laney, ${ }^{94}$ and fired at him. He returned fire and shot and killed Kenneth Crall. ${ }^{95}$

At his manslaughter trial, Laney claimed self-defense. The appellate court, however, ruled that as a matter of law, he was not entitled to a selfdefense instruction because he could not demonstrate the necessity for the taking of human life. ${ }^{96}$ Laney certainly faced an imminent threat of death at the time he resorted to lethal force. In the court's view, however, it was required to look to preceding events to assess necessity. Because Laney stepped into the street and placed himself in the position where he would be threatened by the mob when he could have avoided it, he was responsible for creating the confrontation. ${ }^{97}$ Since Laney's own choices played a role in the events that led up to his use of lethal force, the court deemed its use

Can "Resistance Against Kidnapping" Justify Lethal Self-Defense Against Incapacitated Batterers?, 102 COLUM. L. REV. 729, 733 (2002).

90294 F. 412, 413-14 (D.C. Cir. 1923).

91 Id. at 413.

$92 \mathrm{Id}$.

$93 \mathrm{Id}$.

${ }^{94}$ Id. In his words, "While I was in the areaway between 617 and 619 , the mob came across from the south side of the street, firing and hollering 'Let's kill the [epithet]!"'Id.

95 Laney, 294 F. at 413.

${ }^{96}$ Laney objected to the self-defense instructions given at his trial. The appellate court concluded that because he was not entitled to claim self-defense at all, he was not prejudiced by the instructions given. Id.

97 In the court's view, Laney, having arrived at a "place of comparative safety"- the alleyway in which he had concealed himself-should not have returned to the street. $I d$. at 414 . 
unnecessary and therefore unjustified. ${ }^{98}$ The court's view of necessity reached back in time, requiring Laney to do "everything in his power, consistent with his safety, to avoid the danger and avoid the necessity of taking life."99 If he could have avoided the attack, he was obliged to do so, at risk of losing the claim of necessity and the concomitant right of selfdefense. 100

Laney is an old case laden with racist views of autonomy, dignity and privilege. Yet its vision of necessity - and the broad frame that it implies for an analysis of a self-defense claim-persists. Jury instructions in the District of Columbia, based on the principles articulated in Laney, remain viable today. 101 One instruction provides: "one who deliberately puts himself/herself in a position where s/he has reason to believe that his/her presence will provoke trouble cannot claim self-defense."102 Nor is this approach limited to a lone jurisdiction. Other states permit the factfinder to consider the broad frame in which an encounter arose in assessing a claim of

\section{Id. at 414 :}

Hence, when he adjusted his gun and stepped out into the areaway, he had every reason to believe that his presence there would provoke trouble. We think his conduct in adjusting his revolver and going into the areaway was such as to deprive him of any right to invoke the plea of self-defense.

See also Moore v. State, 160 S.W. 206 (Ark. 1913). Moore was accused of murdering her husband, who she claimed assaulted her with a knife when she went, armed, to find him at a house of ill repute. Moore argued that the jury should have been instructed that she "had a legal right to go to the home where she believed they were staying and to carry with her a weapon to defend herself." The court rejected that claim, finding that "it permits one who is expecting trouble, and probably looking for it, to be armed and ready for it when it comes."

${ }^{99}$ Laney, 294 F. at 414.

100 "If one has reason to believe that he will be attacked, in a manner which threatens him with bodily injury, he must avoid the attack if it is possible to do so, and the right of self-defense does not arise until he has done everything in his power to prevent its necessity." Id.

${ }^{101}$ Until 1993, the language of a pattern jury instruction in the District of Columbia was taken almost verbatim from Laney. See D.C. PATTERN JURY INSTRUCTION $§ 5.16(B)$ ("Before a person can avail himself of the plea of self-defense against a charge of homicide, he must do everything in his power, consistent with his own safety, to avoid the danger and avoid the necessity of taking life."). This language was omitted in 1993 because of concern that it implied a duty to retreat. Practice Commentary to D.C. PATTERN JURY INSTRUCTION $§ 5.15$.

102 1-1 CRIM. JURY INSTRUCTIONS FOR THE D.C. FORM INSTRUCTION § 5.16(B) (2007). The commentary following the instruction expressly cites Laney for the proposition that "self-defense is not available to a defendant who deliberately puts himself in a position where he has reason to believe that his presence will provoke trouble, even if his purpose in putting himself in that position was benign." Id. 
self-defense, and ask whether the defensive actor should have done something different, earlier in the encounter, that could have avoided the need to use lethal force.

This approach is evident in jury instructions on self-defense. A review of these instructions indicates that they suggest to factfinders, in a variety of broad formulations, that the defendant claiming the lawful use of force must not have played a role in creating the circumstances giving rise to the need to use that force. The instructions do little to define the parameters of that constraint, inviting factfinders to expand the frame to consider significant expanses of prior conduct, and to deny the actor a claim of self-defense on that basis.

\section{1. "Without Fault," and Other Vague Framing Formulations}

Jury instructions in self-defense cases often contain broad language about the actor's obligation to avoid the situation, susceptible of an interpretation that broadens the frame of the inquiry. While at least some of these instructions appear to be intended to preclude the initial aggressor from claiming self-defense, they are phrased more broadly than that and are not limited to that context. Instead, they are typically expressed in brief and vague language that opens the door to the framing issue.

Many instructions suggest that a defendant who played some role in creating the situation that led to the use of force cannot rely on self-defense. One such formulation requires that the actor claiming self-defense not be "at fault." Ohio's instruction, for example, requires a defendant claiming selfdefense to prove that "he/she was not at fault in creating the situation giving rise to" the event in which death or injury occurred. ${ }^{103}$ Virginia's instruction requires that the defendant be "without fault" in bringing on the violent encounter. 104 The notion of being "free from fault" is mirrored in treatises, which state a similar requirement. ${ }^{105}$ While Prof. Dressler terms the

1034 OHIO JURY INSTRUCTIONS $\$ 411.31(2)$ (2006); see also 4 OHIO JURY INSTRUCTIONS $\S 411.31(3)(\mathrm{A})$ (2006).

104 VIRGINIA MODEL JURY INSTRUCTIONS-CRIM. No. 52.500 (requiring a conclusion "that the defendant was without fault in provoking or bringing on the [. . difficulty]"). The subsequent instruction, 52.510, provides ways that a defendant "to some degree at fault" is able to reclaim the privilege. See also the commentary following MD. CRIM. PATTERN JURY INSTRUCTIONS $\S 5: 07$ (2006), which states that self-defense "requires a faultless victim." AmJur states the general principle granting the privilege of self-defense to "one who, free from fault in bringing on a difficulty, is attacked . . ." 40 AM. JUR. 2D Homicide § 163 (2008).

105 See, e.g., PERKINS \& BOYCE, supra note 48, at 1115 ("One who is himself free from fault is privileged to use force in the effort to defend himself against personal harm threatened by the unlawful act of another ...." (footnote omitted)). 
requirement of being "free from fault in the difficulty" "an overstatement,"106 it is a common formulation in a jury instruction. 107

There are also formulations in which a defendant responsible for "trouble" or "difficulty" is deprived of a self-defense claim. The District of Columbia instruction provides, "One who deliberately puts himself/herself in a position where $\mathrm{s} / \mathrm{he}$ has reason to believe that his/her presence will provoke trouble cannot claim self-defense."108 Louisiana precludes one who "brings on a difficulty" from claiming self-defense "unless he withdraws from the conflict"; 109 the phrase "brings on a difficulty" is not defined. Minnesota's instruction provides that "[i]f the defendant began or induced the incident that led to the necessity of using force in the defendant's own defense," the defendant must decline an assault, try to escape, and inform the adversary of a desire for peace before he can resort to self-defense. ${ }^{110}$ A Massachusetts instruction requires a person claiming self-defense to "avail[] himself or herself of all proper means to avoid physical combat."111

Framing issues are also presented by an instruction like, "[a]s part and parcel of the 'necessity' requirement that inheres in every claim of lawful self-defense, evidence that a defendant could have safely avoided using

106 See DRESSLER, supra note $23, \S 18.02$; see also Rosen, supra note 70 , at 396 ("society does not now, nor has it ever," required individuals to go to great lengths to flee from unlawful threats).

No matter how clear it was to Gary Cooper that somebody would end up dead if he did not leave before the train carrying his enemy arrived at 'High Noon,' our culture allows him to stay in town and affords him the right to kill in self-defense when the bad guys come after him.

Id. (footnote omitted).

107 DRESSLER, supra note 23, $§ 18.02$ :

For example, if $D$ calls $V$, an acquaintance, 'a jerk,' to which $V$ take[s] such umbrage that he pulls out a gun and menaces $D$ with it, $D$ is justified in killing $V$ (assuming that the other requirements of the defense are met), although $D$ was not entirely free from fault in the conflict.

108 1-1 CRIM. JURY INSTRUCTIONS FOR DC FORM INSTRUCTION $\S 5.16$ (2007). This instruction is derived from the language of Laney. The instructions provide that this part should be given "[w]here some evidence is introduced that the defendant might have been the attacker," but nothing in the instruction restricts the factfinder's consideration of this broad language to that circumstance. Id.

109 LA. CRIM. JURY INSTRUCTIONS AND PROCEDURE § 6.33 (2d. ed. 2009-10).

110 MINN. JURY INSTRUCTION GUIDES-CRIM. $\$ 7.07$ (5th ed. 2009). The section is captioned "Self-Defense-Revival of Aggressor's Right of Self-Defense," but it is not clear that the captions are read to the jury, and the language "began or induced the incident" could be understood to encompass much more than being the initial aggressor in a violent encounter.

111 Mass. SUPER. CT. CRIM. Practice JURy InSTRUCTIONS, Vol. II, § 3.6. 
deadly force is normally relevant in determining whether it was reasonably necessary for him to kill..." 112 The instruction does not advise the factfinder as to when the obligation of safe avoidance arises, opening the door to a broad and variable conception of the frame in which to assess whether the defendant met the obligation to avoid the encounter. Such language has been interpreted to suggest that the actor had an obligation to avoid not just aggression, but any earlier acts that played a role in creating the need for self-defense. 113

If the purpose of these instructions is to prevent a defendant who is the initial aggressor or a participant in a mutual affray from claiming selfdefense, there are clearer ways of saying so. New Mexico's uniform jury instruction, for example, provides that "Self-defense is not available to the defendant if he [started the fight or agreed to fight]."114 Most instructions, however, do not limit the factfinder's consideration of the situation in this way. 115

112 People v. Riddle, 649 N.W.2d 30, 46 (Mich. 2002).

113 See Goins v. State, 21 N.E. 476, 481 (Ohio 1889), discussed infra note 161.

114 N.M. UNIF. JURY INSTRUCTIONS-CRIM. $\$ 14-5190$ (2009). The instruction then sets out those circumstances where an initial aggressor or participant in a mutual affray can regain the right of self-defense. Id.; see also PA. SUGGESTED STANDARD CRIM. JURY INSTRUCTIONS $\S 9.501$ (2d. ed. 2005) (providing that a defendant is not justified if "the defendant provoked the use of force against [him] [her] by engaging in conduct that showed that [he] [she] intended to cause death or serious bodily injury to the alleged victim ...."); WASH. PATTERN JURY INSTRUCTIONS $\$ 16.04$ (3d. ed. 2008) (providing that if the jury finds "that the defendant was the aggressor, and that defendant's acts and conduct provoked or commenced the fight, then self-defense ... is not available as a defense.").

115 Another alternative would be to limit the restriction on self-defense to one who brings on the difficulty by virtue of a wrongful act. See, e.g., Jones v. Commonwealth, 216 S.W. 607, 608 (Ky. 1919) (limiting right of self defense to "one who brings on the difficulty by his own wrongful act"); see also Hall v. Commonwealth, 270 S.W. 35, 38 (Ky. 1925) ("Any wrongful or unlawful act of accused, which is reasonably calculated to an affray or deadly conflict, and which provokes the difficulty, is such aggression or provocation as deprives him of the right of self-defense."). This would still permit the expansion of the frame if the accused's conduct were a violation of law. See, e.g., State v. Corchado, 453 A.2d 427, 429 n.4 (Conn. 1982) (state's requested instruction provided that "any act of the accused in violation of law and reasonably calculated to produce the occasion amounts to bringing on the difficulty and bars his right to assert self-defense as a justification or excuse for a homicide"); People v. Newcomer, 50 P. 405, 407 (Ca. 1897) (upholding instruction that a "cause which originates in the party ... himself, ... in a danger which he has voluntarily brought upon himself by his own misconduct and lawlessness" cannot support a self-defense claim). 


\section{Applying the Formulations in the Real World of Caselaw}

How do the courts reconcile these statements of the law with the principle that self-defense law does not require an expansion of the frame? As one might expect, inconsistently. In some cases, the defendant is denied a self-defense claim because his earlier actions placed him in a situation he might have avoided had he made better decisions. Consider Commonwealth v. Jones, 116 a Pennsylvania case. Jones went to the home of his common law wife's son to pick up some belongings. ${ }^{17}$ Jones and the son got into a fight; Jones departed, but later learned from his common law wife that the son and several others were driving to his house. ${ }^{118}$ Jones asked her to call the police, then dressed, armed himself with a kitchen knife, "and left the premises to await the arrival of the carload of hostile youths." 119 After "[a] flare, some stones, and a piece of a bicycle were thrown at the house," Jones went to confront the youths and struck one of them. ${ }^{120}$ The youth, in turn, pushed Jones to the ground; Jones slashed at the young man with a knife and injured him severely. ${ }^{121}$ Jones was charged with aggravated assault and convicted in a bench trial; he claimed that he should have been acquitted on the ground of self-defense. ${ }^{122}$ The court rejected this claim because Jones became involved in a confrontation he could have avoided. ${ }^{23}$ It first held that, to claim selfdefense, the defendant must "have been free from fault in provoking or continuing the difficulty which resulted in the [injury]." 124 Jones, by leaving his home to confront the youths, was "continuing the difficulty" and therefore could not claim self-defense. Because the police had already been called, it was not "immediately necessary" for Jones to use force to protect himself. 125 " $[\mathrm{B}] \mathrm{y}$ coming onto the porch when the action was not reasonably necessary, appellant was 'continuing the difficulty' that resulted in the assault." 126

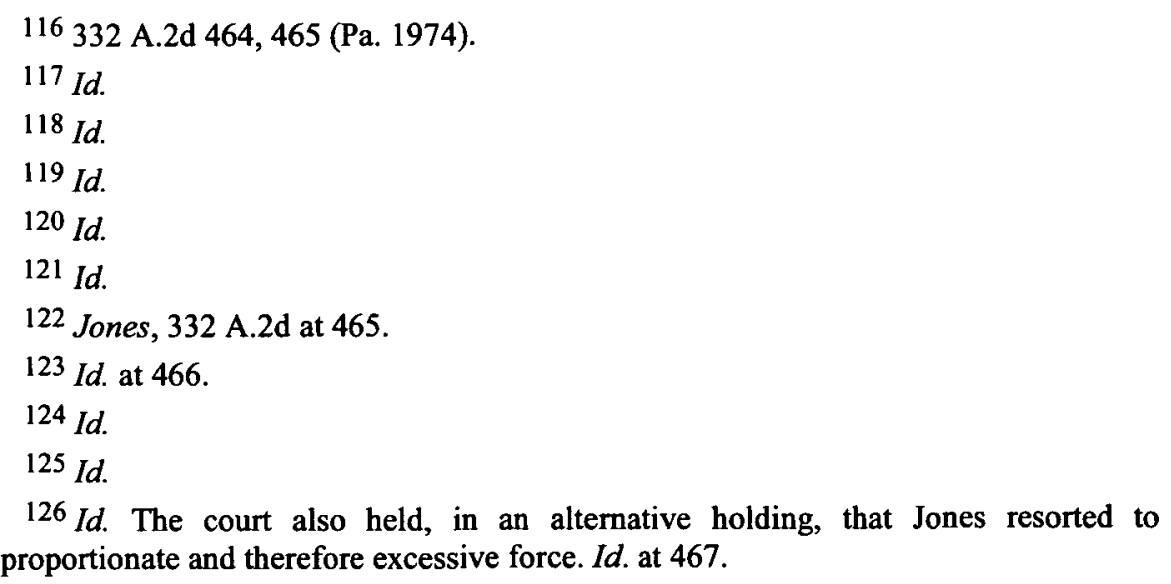


By contrast, in State v. Corchado, ${ }^{127}$ the court held that instructions that permitted the jury to consider an expanded frame were reversible error. In Corchado, the defendant went to his girlfriend's house and saw a car belonging to the victim, Ventura, parked outside. ${ }^{128}$ Corchado confronted Ventura and asked if he was "fooling around" with the girlfriend. Ventura responded by drawing a gun; Corchado fled and reentered the girlfriend's house. ${ }^{129}$ Half an hour later, believing that Ventura was gone, Corchado went out on the street. When he saw Ventura there, he approached him and asked him again if he was "fooling around" with the girlfriend. When Ventura responded with a "mean smile," Corchado slapped him. Ventura pulled out his gun again; believing that he was going to be shot, Corchado shot and killed Ventura. ${ }^{130}$ The appellate court held that an instruction that required Corchado to be without fault entitled him to a new trial:

We believe that the words "without fault"... erroneously deprived the defendant of the fair intendment of [the statute]. The term "without fault" was neither explained nor defined. The statute does not provide that a person be "without fault" to come within its reach. It is not difficult to visualize self-defense situations where, as here, there is some fault on both sides. ${ }^{131}$

The court seemed particularly concerned that the defendant's slapping the victim might have led the jury to believe that it could not find that he acted in self-defense:

Much is made of the slap given the victim by the defendant just before the fatal shooting, after the former had made a "mean smile." The slap, of course, is to be viewed not only as a response to the "mean smile" but also in light of the earlier altercation in which the victim had pointed a gun at the then unarmed defendant after the defendant had accused him of "fooling around" with Bosco. Thus, to a layman on a jury, there was some "fault" on both sides. Yet "without fault," open ended as it was in context, propounded an absolute for the jury while the statute does not. 132

Other prior conduct that is viewed as having created the situation is sometimes viewed as sufficient to deprive the defendant of a claim of selfdefense. In State v. Robinson, for example, Robinson was participating in

127453 A.2d 427 (Conn. 1982).

128 Id. at 428 .

${ }^{129}$ Id.

${ }^{130}$ Id. at 428-29.

131 Id. at 432-33.

132 Id. at 433. 
selling cocaine out of an apartment. ${ }^{133}$ Several men came, armed with guns, to rob the apartment; one fired several shots into the apartment. ${ }^{134}$ Robinson, hiding behind a closed door, fired his gun in response and killed another person involved in the drug-selling enterprise. ${ }^{135} \mathrm{He}$ was convicted of murder and argued that the jury should have been instructed on transferred intent self-defense. ${ }^{136}$ The court rejected his claim on the ground that Robinson, by participating in the cocaine sales, "was at fault in creating the situation that led to the affray." 137 Because he "intentionally assumed a primary role in the criminal enterprise that was operating out of the residence" and acquired a firearm to protect the enterprise, he was to blame for what happened.138 "Although the evidence indicated that intruders did in fact enter the residence and that Robinson was therefore not solely at fault in the events that led to the affray, his fault was such that he should not have been given the benefit of the self-defense instruction."139

Far from the clarity envisioned by contemporary commentators, jury instructions on necessity in the context of self-defense create the opportunity for factfinders to expand or contract the frame in a way that deprives an actor of an otherwise viable claim of self-defense for playing a role in creating the situation that gave rise to the need for self-defense in the first place.

Another area that creates ambiguity about the appropriate scope of the frame is the notion that the factfinder ought to make a generalized inquiry into the "reasonableness" of the defendant's conduct. One situation in which this problem arises is when the prosecution has suggested that the defendant had the opportunity to retreat, but the jurisdiction does not require retreat. 140 The court may respond that the issue was nonetheless appropriate for the factfinder to consider in assessing the "reasonableness" of the defendant's behavior. ${ }^{141}$ The defendant's failure to retreat-even in a jurisdiction with a

133726 N.E.2d 581, 583 (Ohio Ct. App. 1999).

134 Id.

135 Id.

136 Id. at 585 .

137 Id.

138 Id.

139 Robinson, 726 N.E.2d at 585. The court also held in the more convincing alternative that Robinson did not offer sufficient evidence to indicate that he reasonably believed he faced an imminent danger of death, since he fired through a closed door without figuring out who was outside or whether he was at risk. Id. at 585-86.

140 See, e.g., Allen v. State, 871 P.2d 79, 93 (Okla. Crim. App. 1994) ("While we do not overrule our earlier holdings that a party has no duty to retreat from a confrontation, we believe the possibility of escape should be a recognized factor in determining whether deadly force was necessary to avoid death or great bodily harm.").

141 See, e.g., Commonwealth v. Harris, 380 N.E.2d 642, 646 (Mass. 1978): 
no-retreat rule--is deemed relevant to whether he acted "reasonably" in using lethal force. That opens the frame to consideration of the defendant's broader choices. ${ }^{142}$

The District of Columbia's current approach to self-defense is similar. Termed the "middle ground," it "imposes no duty to retreat, but it "permit[s] the jury to consider whether a defendant, if he safely could have avoided further encounter by stepping back or walking away, was actually or

The judge did charge the jurors to consider all the conditions existing at the time and place of the shooting in deciding (a) whether the defendant "had reasonable grounds to believe and actually did believe that he was in imminent danger of death or serious bodily harm . . . from which danger he could save himself only by using deadly force against his assailant," (b) whether "he, the defendant, had availed himself of all proper means to avoid physical contact before resorting himself to defense by the use of a deadly force or a deadly weapon," and (c) whether the force used by the defendant was reasonable or was excessive in all the circumstances of this case. The court held this a correct statement of the law.

See also Brown v. United States, 256 U.S. 335, 343 (1921) ("Rationally the failure to retreat is a circumstance to be considered with all the others in order to determine whether the defendant went farther than he was justified in doing."). But see LA. REV. STAT. ANN. $\S 14: 19$ (D) (2007) ("No finder of fact shall be permitted to consider the possibility of retreat as a factor in determining whether or not the person who used force or violence in defense of his person or property had a reasonable belief that force or violence was reasonable and apparently necessary to prevent a forcible offense or to prevent the unlawful entry.").

142 See, e.g., State v. Renner, 912 S.W.2d 701, 703 (Tenn. 1995). Renner came to his former girlfriend's home to visit their son. The victim, Shuttles, was the girlfriend's new boyfriend; he was at the apartment when Renner arrived. Renner argued with Shuttles, and tried to convince his former girlfriend to resume their relationship and to end her relationship with Shuttles. Renner then went into the kitchen; he claimed to hear Shuttles load a firearm in the living room. Fearing for his safety, Renner pulled out a firearm and decided to leave, passing through the living room - where the front door was - to leave the apartment. Renner contended that Shuttles threatened to kill him, and that he responded with gunfire; Renner killed Shuttles. At trial, the prosecutor asked Renner if he could have left the apartment from the kitchen, rather than going through the living room, and raised this issue again in closing argument, suggesting that "it afforded Renner a way out, which, if taken, would have permitted him to avoid a confrontation with Shuttles in the living room." State law did not require retreat, and Renner contended that the prosecutor's arguments suggested to the jury that retreat was required. The appellate court rejected the argument. Although retreat was not required, the question was nonetheless relevant, the court held, to the jury's analysis of, inter alia, "the circumstances under which the confrontation occurred" and "whether Renner's conduct under the circumstances was reasonable." Id. at 704; see also Gant v. United States, 83 A.2d 439 (D.C. 1951); State v. Morgan, No. 03C01-9408-CR-00305, 1997 WL 110022 (Tenn. Crim. App. Mar. 13, 1997). 
apparently in imminent danger of bodily harm." 143 This approach has been accepted in other jurisdictions as well. ${ }^{144}$ Even outside the context of retreat, the reasonableness inquiry can take into account actions that preceded the ultimate violent encounter, asking the trier of fact to consider "all" the circumstances, broadly defined. One court approved an instruction which provided, "[i]is the totality of everything which took place from which you must decide whether or not the defendant was inviting trouble or whether he wasn't."145

This attempt to instruct jurors that retreat is not required, but that reasonableness might require it anyway seems both to undermine the noretreat principle ${ }^{146}$ and to result in utterly incomprehensible guidance to the factfinder. Consider this instruction given in a Michigan case:

143 Cooper v. United States, 512 A.2d 1002, 1004 (D.C. 1986), quoting Gillis v. United States, 400 A.2d 311, 313 (D.C. 1979). The court explained that "the instruction given did not impose a duty to retreat, but allowed a failure to retreat, together with all the other circumstances, to be considered by the jury in determining whether the case was truly one of self-defense." 512 A.2d at 1004-05; see also Josey v. United States, 135 F.2d 809, 810 (D.C. Cir. 1943).

144 See, e.g., United States v. Blevins, 555 F.2d 1236, 1239 (5th Cir. 1977) (applying federal law and approving an instruction that provided that, while retreat was not required, "if the defendant could have safely retreated and did not do so, his failure to retreat is a circumstance which you may consider together with the other circumstances in the case, in determining whether he went farther in repelling the danger, real or apparent, than he was justified in doing under the circumstances"); State v. Provoid, 266 A.2d 307, 310 (N.J. Super. Ct. App. Div. 1970) (upholding charge that provided, in a nonretreat jurisdiction, "[t]he opportunity to retreat... is a factual element to be considered ... together with all other surrounding circumstances in determining only such resistance and force as appeared to be necessary under all the circumstances.").

145 Commonwealth v. McComb, 341 A.2d 496, 499 (Pa. 1975). McComb had a disagreement with the deceased about money. $I d$. at 497 . McComb agreed to meet the deceased at 7 p.m. Id. After several interactions during the day, McComb arrived at the appointed time, pulled out a gun, and shot and killed the deceased. Id. at 498 . He objected to an instruction directing the jury to consider the events of the entire day in deciding whether McComb was the aggressor in the encounter. Id. The court rejected McComb's claim that the instruction reproduced in text inappropriately expanded the scope of the jury's consideration. Id.

To determine the reasonableness of the use of a deadly force, the opportunity to retreat, the role of the accused in provoking or escalating the difficulty, the trier of fact is required, not only to evaluate the conduct of the appellant during the final confrontation but also to view it in light of those circumstances that preceded and precipitated that final confrontation.

McComb, 341 A.2d at 499.

146 Prof. V.F. Nourse raises a similar concern with regard to the issue of imminence. See generally Nourse, supra note 47 . In her study of cases purporting to deal with imminence as an element of a claim of self-defense, she notes that in some cases 
By law, a person must avoid using deadly force if he can safely do so. If the defendant could have safely retreated but did not do so, you can consider that fact along with all the other circumstances when you decide whether he went farther in protecting himself than he should have. However, if the defendant honestly and reasonably believed that it was immediately necessary to use deadly force to protect himself from an [imminent] threat of death or serious injury, the law does not require him to retreat. He may stand his ground and use the amount of force he believes necessary to protect himself. ${ }^{147}$

It is hard to imagine this instruction making any sense at all to the average juror. More significantly, the invitation to consider "all the ... circumstances" in determining "whether [the defendant] went farther in protecting himself than he should have" opens the frame to considering all of the defendant's prior conduct. ${ }^{148}$ The concept of reasonableness as a

"imminence serves as a proxy for 'alternatives"'-that is, the court concludes that there is no imminent threat because the actor had possible alternative courses of action. Id. at 1267. She further notes that if that is the case,

then imminence may operate as a retreat rule-even in those jurisdictions or situations that do not require retreat. A court that asks whether the threat was imminent and means by this question whether the defendant had any better, lawful choice is demanding the kind of second-guessing of alternatives that no-retreat jurisdictions do not demand. The jury, told that it need not ask why the defendant did not go through the kitchen door, is still invited to ask the same question, albeit in temporal form-did the defendant have the time to go through the kitchen door? Thus, in the same case, a jury may be told to ignore the fact that the defendant could have run through the door (no retreat rule) and, at the same time, that they must deny the defense if he could have run through the door (imminence rule).

Id. at $1267-68$ (footnotes omitted).

${ }^{147}$ People v. Riddle, 649 N.W.2d 30, 36-37 (Mich. 2002). The court concluded that this instruction provided clear direction to the jury.

$148 \mathrm{Id}$.

We reaffirm today that the touchstone of any claim of self-defense, as a justification for homicide, is necessity. An accused's conduct in failing to retreat, or to otherwise avoid the intended harm, may in some circumstances... indicate a lack of reasonableness or necessity in resorting to deadly force in self-defense. For example, where a defendant "invites trouble" or meets non-imminent force with deadly force, his failure to pursue an available, safe avenue of escape might properly be brought to the attention of the factfinder as a factor in determining whether the defendant acted in reasonable self-defense.

Id. at 39. The court went on: "If it is possible to safely avoid an attack then it is not necessary, and therefore not permissible, to exercise deadly force against the attacker." Id. at 40 . 
critical component of necessity, accordingly, creates the possibility of a broad framing inquiry. ${ }^{149}$

\section{E. Framing Consistency and Equity Concerns}

A flexible approach to the framing inquiry has its appeal. Difficult issues of self-defense typically arise in cases involving escalating encounters, threats and counter-threats, and numerous untaken opportunities to avoid the ultimate violent engagement. ${ }^{150}$ It is understandable that one might want to ask a decisionmaker to make a less structured and more justice-oriented inquiry, one that assesses the reasonableness of the behavior of the actor claiming self-defense under all the circumstances, and creates the potentialthough not the obligation - to open the frame to a broad consideration of all the events leading up to the ultimate, lethal encounter. ${ }^{151}$ The temptation to

149 Commonwealth v. Camp, 330 A.2d 844 (Pa. 1975). Camp, a postal worker, was approached several times by the victim, who demanded that defendant turn over the checks he was delivering. Id. at 845 . Defendant agreed to meet the decedent at a bar. Id. He went there with a weapon; when he thought he saw the victim reach for a gun, he fired, killing the decedent. Id. The court rejected defendant's claim of self-defense, concluding that, "the appellant, rather than being free from fault in provoking or continuing the difficulty which resulted in the killing, was directly responsible for its occurrence." Id. at 846. The court followed that analysis with the conclusion, "[a]ppellant went to the bar armed and looking for the persons who threatened him. This sort of conduct takes this homicide out of the category of self-defense." Id.

${ }^{150}$ See Garrett Epps, Any Which Way But Loose: Interpretive Strategies and Attitudes Toward Violence in the Evolution of the Anglo-American "Retreat Rule," 55 LAW \& CONTEMP. PROBS. 303, 303-04 (1992) (describing the "easy case" of selfdefense- "[a] traveler on a dark road is set upon by an armed stranger"- and contending that "the majority of homicides take place after ambiguous confrontations between persons who know each other and have a history of involvement and conflict.").

151 See, e.g., Commonwealth v. Correa, 648 A.2d 1199, 1203 (Pa. Super. Ct. 1994) (where victim came to defendant's apartment building, banged on the door, and yelled threats, defendant was not entitled to claim self-defense because he let the victim into the building). The court rejected defendant's claim that the victim posed a lethal threat. $I d$. "Correa could not have believed that he was in imminent danger from behind a locked door .... [A] reasonable person would have stayed upstairs, behind two locked doors, and waited for the police to arrive." Id. at 1202-03; see also Brown v. United States, 619 A.2d 1180, 1182 (D.C. 1992) ("The trial court under these circumstances properly concluded that appellant had many options, such as entering his aunt's house, remaining in his auto and driving directly home, or telephoning the police.... Appellant cannot raise a legitimate self-defense claim when he went out of his way to look for trouble."). 
ask whether the actor ought to have done something different that would have avoided the situation is almost irresistible. ${ }^{152}$

Such an unguided inquiry ${ }^{153}$ does, however, contain the potential for biased and inconsistent application. If we compare the Adler case, discussed supra, with the Laney case, we might conclude that the races of the defendants and their assailants drove the very different results in those two cases. In Adler, the defendant and Johnson, the deceased, "engaged in a quarrel." 154 During the quarrel, Adler initiated aggressive behavior, tearing a three-foot length of board from a fence and chasing Johnson with it. ${ }^{155}$ Johnson, in response, went into an alley and picked up some pieces of brick and began throwing them at Adler. Adler ran into a grocery store, pursued by Johnson "and another man, who had a knife open in his hand." In the meantime, a mob had gathered, "yelling, 'Hit him!' 'Head him off!' 'Catch him!' etc." 156 Adler stayed briefly in the store, then emerged "with a revolver in his hand." About 200 persons had gathered. ${ }^{157}$ Someone told Johnson that Adler had a gun and was going to shoot. "Johnson was then from 80 to 90 feet from Adler, and began running, when Adler took after him, and fired

152 Consider, for example, the discussion of the Bernard Goetz case in Cynthia Kwei Yung Lee, Race and Self-Defense: Toward a Normative Conception of Reasonableness, 81 MINN. L. REV. 367, 419 (1996):

An even stronger argument can be made that it was not necessary for Goetz to shoot at the youths to defend himself. Goetz could have chosen less violent means of resolving the conflict. He could have said 'No' to the youths' demand for money. He also could have moved to another section of the subway car-perhaps even another car altogether. Goetz might have given the youths something less than the five dollars they requested. Or, Goetz could have warned the youths not to bother him by showing them his gun (not shooting it), and then he could have walked away. Instead, Goetz's immediate response was to fire upon the youths....

See also id. at 435-46 (discussing another case and arguing that the defendant "easily could have avoided any confrontation by permitting them to leave"); id. at 475 (arguing for a "no less drastic alternatives" requirement for acts of self-defense based on a claim of necessity and imminence).

153 See A.J. Ashworth, Self-Defence and the Right to Life, 34 CAMBRIDGE L.J. 282, 287 (1975) (critiquing the reasonableness approach because "it says absolutely nothing about either the rights and duties of the individual or the principles upon which actual cases should be decided").

154 State v. Adler, 47 S.W. 794, 794 (Mo. 1898).

155 According to the court, he "ran Johnson across Sixth street, then west on the same street; Adler pulling off, as he went along, a piece of plank, from three to four feet in length, from a board fence or advertisement sign." Id.

$156 \mathrm{Id}$. at 794-95.

$157 \mathrm{Id}$. at 795. 
two shots at him from a pistol." Shot in the back, Johnson died within five minutes.

In both cases, an individual, pursued by a mob, responded to a lethal threat with deadly consequences. In Adler, however, the mob was mostly black, as was the victim, and the defendant was white. ${ }^{158}$ In Adler, the court imposed no obligation on the defendant to avoid the altercation that resulted in the loss of life, however foreseeable it might have been; it did not expand the frame to require him to choose an alternative that would not be provocative to his assailant; it did not suggest that his emerging from a place of comparative safety - the store-with his weapon at the ready invited the lethal affray. ${ }^{159}$ Our conclusions based on the "race-switching" nature of these two cases ${ }^{160}$ suggest that permitting decisionmakers the uncabined discretion to expand or contract the frame in which they assess necessity creates the opportunity to exercise bias and produce inequitable and unjust results. ${ }^{161}$

This is particularly troubling because the exercise of bias is most likely to take hold in the closest and most difficult cases. This is a reflection of the "liberation hypothesis," which suggests that, in cases where the facts are strong or weak and very clear, the danger of discrimination or arbitrariness is low, but where the facts are less clear, factfinders are "liberated" from the

$158 I d$.

159 Adler's conviction was, in fact, reversed, partly on the ground that one of the instructions given unduly expanded the frame. Id. at 796.

160 See Lee, supra note 152 , at 422 (suggesting that "race-switching . . . can be a useful vehicle to test whether racial stereotypes have influenced one's assumptions about a given case."). For an example of judicial race-switching, see Rhodes v. State, 72 S.E. 518 (Ga. Ct. App. 1911).

161 The court recognized this concern in Goins v. State, 21 N.E. 476, 481 (Ohio 1889). Overturning the conviction of a black man who was accused of aiding and abetting the murder of a member of a white mob that was attacking the defendant and his companions, the court explicitly rejected a broad instruction requiring the jury to find that defendant was "without fault, and in the peace of the state" before the defendant could claim self-defense. The court concluded that the jury might have found this principle violated based on the fact that

one of these colored men was drunk; one or more of the others slightly in liquor; that their conduct was regarded as insolent and offensive; that they had been ordered to go home by a peace officer-they may have well supposed that colored men so conducting themselves were not free from fault and not in the peace of the state, and therefore not clothed with the right of self-defense. The jury should have been made to understand that .... [N] otwithstanding such conduct, the colored men, while in the exercise of their lawful right to pass and repass along the streets of the town, were still clothed by law with the right to defend themselves from the malicious and violent attack of a numerous mob. 
grip of fact, resulting in an increased risk of arbitrariness or discrimination. ${ }^{162}$ The lack of clarity of the framing issue provides a high degree of flexibility to the decisionmaker, creating the opportunity for the exercise of bias in the hardest cases. ${ }^{163}$

Expectations of reasonableness are situational and driven to some extent by the stereotypic expectations of the decisionmaker; rather than permitting the factfinder to choose how to frame the issue, the law should unambiguously decide whether self-defense claims should be addressed under a narrow or broad frame. The Article turns to that issue.

\section{SOlVING THE FRAMING DILEMMA: REJECTING THE BROAD FRAME}

The broad framing inquiry has its appeal. The preservation of human life is undoubtedly critical; if a person goes looking for an encounter that results ultimately in the taking of human life, a broad frame suggests that he should be punished for doing so. A rule that expands the frame and views earlier choices to "look for trouble" as disqualifying the defendant from a selfdefense claim is, however, ultimately unjust.

\section{A. Valuing the Dignitary Interest}

Expanding the frame to penalize the defendant for prior choices that placed him in harm's way winds up having a significant impact on that actor's freedom. Requiring a defendant to avoid a situation which he knows or should know may result in a violent encounter impairs his freedom of movement and of choice. The frontier answer to this problem was to assert unequivocally that an actor behaving lawfully need not avoid situations that might be dangerous and need not go out of his way to avoid another person,

162 See HARRY KALVEN, JR. \& HANS ZeISEL, THE AMERICAN JURY $164-67$ (1966). In their view, "[t]he closeness of the evidence makes it possible for the jury to respond to sentiment by liberating it from the discipline of the evidence." Id. at 165 . This insight was repeated by Justice Brennan in his dissenting opinion in McCleskey v. Kemp, 481 U.S. 279, 325 n.4 (1987), noting that in cases where the evidence as to whether the sentence should be death or life imprisonment was the closest, "impermissible factors such as race play the most prominent role." My thanks to my colleague David Baldus for this helpful analysis.

163 See David C. Baldus, George Woodworth \& Charles A. Pulaski, Jr., EQual JustiCE AND THE DEATH PENALTY 145 (1990) (in analyzing racial factors in the application of the death penalty, "we found that when the crime involved was either extremely aggravated or comparatively free from aggravating circumstances, the choice between a life and a death sentence was relatively clear; and, regardless of racial factors, Georgia prosecutors and juries responded accordingly. By contrast... in the midaggravation range racial factors did play a significant role."). 
even one whom he knew might threaten him with unlawful force. ${ }^{164}$ Adopting the expanded frame definitively rejects this rule.

Contemporary theorists would claim the change is justified, on the ground that preservation of human life justifies some encroachments on the freedom of the individual. Some commentators, for example, have contended that the "sanctity-of-life" principle, as Prof. Kadish terms it, coupled with a "principle of equality," which recognizes that "all human lives must be regarded as having an equal claim to preservation simply because life itself is an irreducible value," and that "[t]he life of the good man and the bad man stand equal,"165 require a retreat rule. Together, these values suggest that the preservation of the life of anyone-even a wrongdoer-is superior to the self-defender's interest in doing as he pleases. Contemporary scholars describe this as an advance, reflecting greater solicitude for the value of any human life, even the life of a wrongful aggressor. ${ }^{166}$

The Model Penal Code, too, reflects this as a value; Section 3.04(b)(ii) provides that the use of deadly force is not justifiable if "the actor knows that he can avoid the necessity of using such force with complete safety ... by complying with a demand that he abstain from any action which he has no duty to take."167 In other words, if an unlawful actor threatens an innocent person with lethal force, but the threat can be avoided if the actor complies with a demand that she abstain from some particular action, the innocent person will not be entitled to claim self-defense if she resists complying with the unlawful actor's demand and is threatened by that actor with lethal force. Some state statutes have adopted this provision of the Code. ${ }^{168}$

164 See supra notes 35-45 and accompanying text.

165 Kadish, supra note 69 , at 880.

166 See, e.g., Dan M. Kahan \& Donald Braman, The Self-Defensive Cognition of Self-Defense, 45 AM. CRIM. L. REV. 1,9 (2008) (noting contemporary doctrine's "humanist commitment" to attaching value to every life). The article suggests that "temptations" to reject departures from these commitments should be avoided:

We do remain tempted to regard some important dignitary ends (honor, equality, autonomy, and the like) as worthy of protection even at the expense of the lives of those who threaten them. We understandably remain tempted to view the lives of those who threaten those interests as worth less than those of persons who live virtuous lives.

Id. at 11 .

167 MOdel PENAL CODE $§ 3.04(2)(b)(i i)$.

168 See, e.g., CONN. GEN. STAT. § 53a-19(b)(3) (2008); DEL. CODE ANN. tit. II $\S$ 464(e)(2) (2008); HAW. REV. STAT. $\$ 703-304(5)$ (b) (2001); ME. REV. STAT. ANN. tit. 17-A, $\$ 108(2)(C)(3)(c)(2007)$; NEB. REV. STAT. $\$ 28-1409$ (4)(b) (1975); N.J. REV. STAT. 2C:3-4(b)(2)(b) (2005): 18 PA. Cons. STAT. § 505(b)(2)(ii) (1998). I have not found a reported case applying any of these provisions. 
The drafters viewed this as a legitimate analogy to the requirement of retreat, which the MPC adopted. If the sanctity of life meant that a person could be required to retreat, he could be required to do other things as well. ${ }^{169}$ This requirement of taking what the explanatory notes refer to as "alternative steps"170 is premised on necessity; "there is no moral claim to exoneration if the actor kills when he clearly need not do so in order to protect himself - when, in other words, he knows that he can avoid the need to kill at no risk to himself." 171

The Code avoided that result in one curious respect: it does not require an actor to comply with affirmative, positive directions from the aggressor, only to comply with a demand to refrain from action. " $[\mathrm{N}] \mathrm{o}$ compliance with a demand for positive conduct is required as an alternative to the use of deadly force." 172 This made sense, in the drafters' view, because "the possible situations that may be embraced in a demand that the actor perform some positive action are infinite in number and variety," and might include a demand that is "outrageous, a demand to which the only answer is that one would rather die than comply."173 If the actor were commanded NOT to do something, however, unless the actor had a legal duty to act, "he would be required to abstain from other types of conduct when he knows that will guarantee his complete safety." 174

How would the MPC approach work in practice? Imagine that Mary is leaving her home to walk to the grocery store when Tyrant, the neighborhood bully, commands her, "Don't leave your house. If you do, I'll kill you." Under the MPC, Mary would be required to obey this direction and stay home if she wanted to retain the privilege of using lethal force in self-

169 "[O]nce it has been decided that the actor should retreat before using deadly force in defense, it seems to follow logically that he should refrain from specified conduct on demand rather than use deadly force, provided that his abstention does not involve him in the violation of law." MODEL PENAL CODE AND COMMENTARIES, part I, vol. 2, at 59 .

$$
\begin{aligned}
& { }^{170} \mathrm{Id} \text {. at } 33 . \\
& { }^{171} \mathrm{Id} \text {. at } 55 . \\
& 172 \mathrm{Id} \text {. at } 60 .
\end{aligned}
$$

173 Model Penal Code 26-27 (Tentative Draft No. 8) (1958). This language was tamed a bit in the final version of the commentary, becoming "outrageous, a demand to which the answer is that one would risk death rather than comply." MODEL PENAL CODE AND COMMENTARIES, part I, vol. 2, at 60 .

174 These constraints, under the Model Code, apply only to the use of lethal force. "[I]f an aggressor demands that the actor not walk to a certain spot where he may lawfully go, the actor may go there and may use moderate force if he believes it necessary to defend himself while going there .... It is only if he must employ deadly force to maintain his freedom of locomotion that the Code imposes a duty to abstain." Id. at 61 . 
defense - that is, if she wanted to walk to the store and, if set upon by Tyrant, to be permitted to respond to Tyrant's unlawful use of lethal force against her. If Mary proceeds to the store, is threatened with lethal force by Tyrant, and in turn responds with lethal force, Mary's act will not be justified, even though her act-walking on a public street-was entirely lawful, Tyrant was a wrongdoer threatening the unlawful use of lethal force, and Mary did not respond with lethal force until she was first threatened unlawfully with lethal force. The drafters of the Model Penal Code and other contemporary theorists viewed it as fair to constrain the freedom of an innocent actor if that was necessary to avoid a lethal altercation.

One could reach the same result by expanding the frame. Asked whether Mary could have avoided the situation, was "looking for trouble," or was "free from fault in the difficulty," a factfinder might properly conclude that Mary could have avoided the whole encounter simply by staying home. If that analysis results in depriving Mary of the privilege of using force in selfdefense, Tyrant can control Mary's behavior, and, in effect, limit her freedom of movement and of choice. ${ }^{175}$

These approaches inappropriately undervalue that actor's dignitary interest. By "dignitary interest," I mean the actor's interest in being permitted to move about freely and to pursue those activities fundamental to a free society, without being subjugated to the unlawful demands of another actor. ${ }^{176}$ To deny actors the claim of self-defense even in a situation in which they respond to an unlawful threat of lethal force with lethal force, based on their previous decisions to go to a place or to take an action that they were legally permitted to take, constitutes a profound encroachment on the dignitary interest. Any rule that constrains the law-abiding citizen's choice of lawful options by requiring her to submit to the unlawful demands of others in order to retain the privilege of self-defense improperly invades that interest. Such a rule does not merely require such an actor to honor the sanctity-of-life principle; it requires her to submit to the subjugation of an aggressive and unlawful actor. This allows bullies effectively to require

175 The Model Penal Code's rule turns on the inherently unconvincing nature of the distinction between positive commands and commands to abstain from conduct. Should the situation be any different if Tyrant orders Mary to "stay in your house"-an affirmative act? The bully who commands, as you leave your home, "turn right, or I'll kill you," is demanding positive conduct. Under the Code's formulation, an actor need not turn right to be entitled to engage in self-defense. However, if the same bully commanded, "don't turn left, or l'll kill you," the failure to turn right would deprive the actor of the justification of self-defense if her noncompliance with the command resulted in the need to use lethal force to save her own life.

176 Whether such a right has constitutional protection is explored in Mitchell F. Crusto, Enslaved Constitution: Obstructing the Freedom to Travel, 70 U. PITT. L. REV. 233 (2008). 
compliance with their demands. ${ }^{177}$ Those demands need not be spoken; they can be implicit and still control the actor's behavior. The comments to the tentative draft of the Model Rule made clear that this rule would apply equally even in the absence of a command: "The same result follows, of course, if there is no demand but the actor knows that he will be attacked if he appears in a certain place." 178

Yet this analysis fails to recognize that, if the actor's chosen course of conduct is lawful, requiring her to avoid it in order not to be deemed to be "looking for trouble" subordinates her free will to that of the wrongful actor. It is the anticipated conduct of the wrongful actor that controls her behavior. If the choice that the actor wishes to make is a lawful one, it is unclear why another person's threatened unlawful and violent action should constrain her personal freedom.

Some writers have trivialized the importance of the dignitary interest, suggesting that it implies that any interference with one's choices in life, however insignificant, justifies violence. Commentators are quick to disparage these notions of dignitary rights, ridiculing the non-retreat rule, for example, as the embarrassing residuary of pioneer machismo, ${ }^{179}$ and suggesting that insistence on freedom of movement is trivial in relation to

${ }^{177}$ Prof. Catherine Carpenter makes a similar argument with regard to a battered partner's obligation of retreat when both partners share a residence: a legal principle that requires the battered spouse to retreat from the shared residence effectively gives the aggressive spouse the power to require the peaceable spouse to leave. Carpenter, supra note 66 , at 690 .

If the innocent cohabitant must retreat because the deadly cohabitant maintains lawful possession, the deadly cohabitant has, in effect, ejected the innocent cohabitant. By requiring the innocent cohabitant to flee, both the broadest form of the cohabitant exception and the limited duty to retreat provide the deadly cohabitant with an authority not granted the innocent cohabitant-the right to eject the other party.

Id.
178 Model PeNal Code 27 (Tentative Draft No. 8) (1958).
179 See, e.g., Richard MAXWELl Brown, No Duty To RETREAT 173 (1991):

Is America entering a period of post-no duty to retreat in which standing one's ground will have less and less appeal in a nation falling away from no duty to retreat and its web of supporting values?... Is a new cluster of values stressing peace (rather than military combat), environmental preservation (instead of environmental exploitation), cooperation (rather than competition), and gentle qualities (rather than the norm of 'macho' masculinity) slowly but surely eroding the traditional American value of no duty to retreat? 
protecting the aggressor's life. ${ }^{180}$ Consider, for example, the following hypothetical, proffered by Prof. Alexander:

Suppose that I live in a town that is near an insane asylum. Further, suppose that I ordinarily have the right to walk the streets freely and to resist aggression. Now consider the situation when several homicidal lunatics have escaped and have been observed going into the town. The police warn all residents, including me, to stay in our homes for a few hours until they can round up the escapees. Nevertheless, because I have a yen for taking a stroll, and because I carry an automatic pistol for protection, I venture outdoors and proceed to take my daily constitutional. Sure enough, I encounter several knife-wielding lunatics who attack me, and I am forced to kill them all.

I do not expect that many, if any, readers will find my conduct justifiable .... In the absence of some very compelling reason, my doing what I ordinarily have a right to do, in a situation in which I know that I will probably have to kill innocent, though aggressive, people in order to protect my life, appears to be Wrong, not Right. ${ }^{181}$

In this hypothetical, the desire of the actor to go where he wishes is presented as trivial or even frivolous; it is plainly clear to the author that an actor's "yen for taking a stroll" should not supersede the right to life of innocent-even if homicidal-actors. The dignitary interest, in this context, seems reduced to simple selfishness; it seems obvious that the whims of an actor whose desire for unfettered freedom results in the loss of innocent lives should be subordinated to the value of those lives. ${ }^{182}$ Nor is he alone; contemporary scholars routinely diminish the significance of the dignitary

180 See, e.g., an instruction offered in an Alabama case: "No balm or protection is provided for wounded pride or honor in declining combat, or sense of shame in being denounced as cowardly. Such thoughts are trash, as compared with the inestimable right to live." Springfield v. State, 11 So. 250, 252 (Ala. 1892).

181 Laurence A. Alexander, Justification and Innocent Aggressors, 33 WAYNE L. REV. 1177, 1183-84 (1987).

182 Similar commentary exists criticizing the no-retreat rule:

A really honorable man, a man of truly refined and elevated feeling, would perhaps always regret the apparent cowardice of a retreat, but he would regret ten times more, after the excitement of the contest was past, the thought that he had the blood of a fellow-being on his hands. It is undoubtedly distasteful to retreat; but it is ten times more distasteful to kill.

Joseph H. Beale, Jr., Retreat from a Murderous Assault, 16 HARV. L. REV. 567, 581 (1902-03). 
interest in light of the much greater interest in the preservation of human life. ${ }^{183}$

While innocent aggressor hypotheticals are an effective tool for testing the theoretical consistency of self-defense law, they are not a good basis for shaping criminal law doctrine. ${ }^{184}$ Aggressors are rarely innocent, which is what makes these situations so peskily hypothetical. In the real world, the dignitary interest is not simply about protecting the trivial right of an uncaring citizen to do what he wishes, at the expense of an innocent actor. Instead, it addresses the right to be free from the subjugation of an aggressor, who is, as a practical matter, highly unlikely to be innocent. In that sense, the dignitary interest is as much about constraining abusers of power as it is about guaranteeing the freedom of those subjected to power. ${ }^{185}$

A principle based on the need to preserve life at all costs seems noncontroversial at first glance. But requiring an actor to avoid the resort to lethal force by doing whatever he could have to avoid the critical encounter permits the bully to rule the streets. In the context of the Laney case, the mob, illegal actors all, were privileged in their threats; they could threaten Laney with death without facing the risk of lawful force in response. The law, in effect, made the obligation to avoid violence Laney's, not the mob's; he lost the right to use self-defense by failing to avoid a confrontation. Taken more broadly, the principle suggests that unlawful actors are privileged to

183 Ashworth argues that the dignitary interest of the actor is outweighed by the need to preserve life: "[S]hould not the minimization of physical violation take precedence over mere freedom of movement? Is there not some analogy with omissions to assist in saving life, where a citizen's general liberty should also be outweighed by a specific social duty?" Ashworth, supra note 46, at 119. Ashworth contends that the law imposes no duty to avoid conflict "in those cases where $\mathrm{D}$ is acting lawfully in remaining at, or going to, a place, realizing that there is a risk that someone will force a violent confrontation there." Id; see also Sangero, supra note 64, at 526 (in a criticism of the autonomy theory of self-defense, "[a] third advantage ... is that the autonomy rationale leads to the highest protection of the rights and liberties of law-abiding citizens. However, protection of this maximum extent is not socially desirable, neither from the perspective of values and morality nor from a practical perspective.").

184 The innocent aggressor problem is defined infra note 190.

185 A.J. Ashworth, supra note 153, at 283 ("'[O]n practical grounds, a liberty to use force in self-defence is essential if members of society are not to be put at the mercy of the strong and unscrupulous."); see also State v. Bristol, 84 P.2d 757, 762 (Wyo. 1938) (court rejects the argument that Bristol ought not to have gone to a restaurant when he had been threatened with assault if he went there; court termed the issue "whether or not the law can afford to encourage bullies to stalk about the land and terrorize citizens by their mere threats"); DICEY, LAW \& THE CONSTITUTION (8th ed. 1915) ("Discourage selfhelp, and loyal subjects become the slaves of ruffians."); HERBERT STEPHEN, DIGEST OF THE CRIMINAL LAW 125, 160 (6th ed. 1904) (if retreat were required, "it would follow that any ruffian who chose to assault a quiet person in the street might impose upon him the legal duty of running away."). 
compel obedience with their implied or explicit direction before a victim can resort to the use of lethal force. The more predictably aggressive and violent the unlawful actor is, the more significant becomes the threatened victim's obligation to avoid him. That encroachment on human dignity exceeds what ought to be required of an individual seeking the right to defend himself.

Scholars routinely recognize autonomy as a theoretical justification for some aspects of self-defense doctrine. ${ }^{186}$ Such a theory looks to the importance of permitting an individual the right to resist threats to his autonomy imposed by unlawful aggression. ${ }^{187}$ This notion that one has the right to resist a wrongdoer is embodied in the prevention of felony aspect of self-defense, ${ }^{188}$ which permits lethal force to be used to resist certain violent and forcible felonies, even if they do not include certain threats of death. It also explains the "castle" doctrine, ${ }^{189}$ has been used to resolve the "innocent aggressor" problem, ${ }^{190}$ and seems inherent in the recent surge of

186 It is sometimes named differently: Prof. Fletcher calls it the "autonomy interest," see Fletcher, supra note 64, at 860 , while Prof. Nourse calls it the "libertarian approach," see Nourse, supra note 47, at 1273.

187 The autonomy principle has been criticized on the ground that it suggests no proportionality limitation; any encroachment on the actor's autonomy could be answered with lethal force. Alexander, supra note 181, at 1180. Prof. Fletcher's response to that contention would be that the encroachment must be significant; not all minimal intrusions on a person's autonomy may be answered with force. See George P. Fletcher, Domination in the Theory of Justification and Excuse, 57 U. PITT. L. REV. 553, 560 (1996) ("every petty interference with ... autonomy" does not justify the use of lethal force).

188 Consider, for example, LaFave and Scott's description of kidnapping and rape as among "the most extreme intrusions on freedom of the person ... even when the crime does not threaten death or serious bodily harm." WAYNE LAFAVE \& AUSTIN W. SCOTT, JR., CRIMINAL LAW 456 n.15 (2d ed. 1986).

189 This permits an individual in his home to resist unlawful entry, even in a jurisdiction otherwise subscribing to the retreat requirement. Fletcher, supra note 64, at 861 ; Kadish, supra note 69 , at 875.

190 See George P. Fletcher \& Luis E. Chiesa, Self-Defense and the Psychotic Aggressor, in CRIMINAL LAW ConVERSATIONS 365, 365 (Robinson, Ferzan, \& Garvey, eds. 2008). The "innocent aggressor" problem asks why an actor is justified in using lethal self-defense against someone who, because of insanity or infancy, would be excused in her use of lethal force. The problem is set out in George P. Fletcher, Proportionality and the Psychotic Aggressor: A Vignette in Comparative Criminal Theory, 8 ISR. L. REV. 367, 371 (1973). Because the aggressor is excused and therefore innocent, applying the equality of life principle suggests that the prospective victim's life is no more worthy than that of the innocent aggressor. Authors Fletcher and Chiesa suggest that it is the innocent aggressor's encroachment on the autonomy of the victim that makes the victim's response justified rather than simply excused. Fletcher \& Chiesa, supra, at 369-71. 
"householder statutes," permitting the use of lethal force in self-defense against home intruders and eliminating any obligation of retreat. ${ }^{191}$

Autonomy, however, is sometimes articulated as a narrowly defined right to physical integrity. As Prof. Fletcher described the principle, "[ $t]$ he underlying judgment must be that the victim has a right to the integrity and autonomy of his body and that he has a right to prevent encroachments upon his living space." 192 The analogy is warfare, and the physical intrusion of the aggressor into one's space constitutes a hostile enemy advance. ${ }^{193}$ The dignitary interest, by contrast, extends more broadly to protect the actor's right to engage in fundamental freedoms of choice and movement.

Absent this conclusion, the bad actor-the threatening bully-owns the streets. In its early American development, self-defense law-in particular, the arguments over the retreat requirement-focused on the actor's interest in personal freedom, conceptualized this way. ${ }^{194}$ The courts recognized the

191 See Jeannie Suk, The True Woman: Scenes from the Law of Self-Defense, 31 HARV. J.L. \& GENDER 237, 263-64 (2008); Jason W. Bobo, Following the Trend: Alabama Abandons the Duty to Retreat and Encourages Citizens to Stand Their Ground, 38 CUMB. L. REV. 339, 359-64 (2008).

192 Fletcher, supra note 190, at 378; see also id. at 380 ("The intrusion upon someone's living space itself triggers a justified response."); Mordechai Kremnitzer \& Khalad Ghanayim, Proportionality and the Aggressor's Culpability in Self-Defense, 39 TULSA L. REV. 875, 881 (2004) (describing protector of autonomy as a person who has not "invaded anyone else's personal space" and "who wishes to defend his own personal space."). The authors later suggest a broader definition of autonomy-"protection of [the actor's] legitimate interests," $i d$. at 882 , but then state that if self-defense protects autonomy, a vigorous duty of retreat should apply. Id. at 882-83. An understanding of autonomy as protecting the actor's right to freedom of movement is not particularly consistent with a strong retreat requirement. See also id. at 883 ("protecting autonomy" is defined as "the defending of personal legitimate interests of the victim").

193 Fletcher, supra note 64, at 862.

194 See, e.g., State v. Bristol, 84 P.2d 757, 762 (Wyo. 1938). In rejecting the contention that the defendant had an obligation to avoid going to a restaurant where he knew an aggressor who had previously threatened him might be, the court argued:

The State thinks that he should have gone home, instead of going to the restaurant. The jury doubtless took that view, and it is not improbable that the fact that he did not go home was the most potent factor in convicting the defendant. And, ethically speaking, that, perhaps, is what he should have done.

Id. The issue, however, required consideration of

ethics and public policy as well. It involves the balancing of the interests between liberty and freedom of movement and the restraint thereof. It involves the question as to whether or not the law can afford to encourage bullies to stalk about the land and terrorize citizens by their mere threats. We hesitate to lay down a rule which would do that. 
autonomy concern not only because of what such a rule meant to the actor forced to flee rather than defend, but what such a rule would mean for a society, largely distant from and unregulated by law enforcement, if unlawful actors knew that the law required their victims to flee rather than defend themselves. ${ }^{195}$ It was that subjugation of the potential innocent victim by the unlawful actor-and the consequences it created for society-to which some courts looked in rejecting the retreat requirement. ${ }^{196}$

To contemporary theorists, these concerns may seem archaic, and relevant only to a frontier culture. But dignitary interests can be equally threatened on the streets of the contemporary American city. Recently, a federal judge reached the same conclusion in a self-defense case that arose on the streets of New York. In Davis v. Strack, ${ }^{197}$ Davis, a twenty-three-year-

Id.; see also State v. Cain, $20 \mathrm{~W}$. Va. 679, 702 (1882) (nonretreat rule "is at least the surest to prevent the occurrence of occasions for taking life; and this by letting the wouldbe robber, murderer, ravisher, and such like know, that their lives are in a measure in the hands of their intended victims"); Fletcher, supra note 64, at 866 (nineteenth-century case law "was divided, as might be predicted, but the weight of authority appeared to favor the principle of autonomy. This commitment to autonomy was expressed in the recurrent line of the opinions that if the defendant was 'in a place that he had a right to be,' then he had the right to stand his ground and vindicate his autonomy.").

${ }^{195}$ Lance K. Stell, Close Encounters of the Lethal Kind: The Use of Deadly Force in Self-Defense, 49 LAW \& CONTEMP. PROBS. 113, 120 (1986):

In an environment which is known to contain aggressors, prohibiting lethal self-help penalizes the law-abiding by causing aggressors to fear defensive violence from the police only and not from their law-abiding victims. It seems objectionable for the law to permit aggressors to gain so much from their victim's disposition to be lawabiding.

One author terms this "rule consequentialism"-the notion that legalizing self-defense will serve as a deterrent to wrongful actors and, in the long run, save lives. FIONA LEVERICK, KILLING IN SELF-DEFENSE 48-49 (2006).

196 Another way to think about this might be to ask what rule would produce the fewest wrongful lethal events. See Stell, supra note 195, at 119 (the question another author wants to ask is, "What lethal force rule will, over the long pull, produce the least amount of wrongful and (potentially) deadly violence in society?"). Stell deems this a pertinent question to theorists of all sorts, but suggests that answering this question would not necessarily produce the right result: "Presumably, rational, self-interested persons have an indirect interest in various policies' social welfare effects, but they are also interested in exercising and protecting their own autonomy." Id. On the frontier, it might have been plausible to conclude that limiting lethal response to unlawful aggressors would encourage their behavior, leading, in the long run to more rather than less wrongful aggression. One author deems this the "consequentialist approach," based on the premise that, "when faced with a choice between the death of the aggressor and the death of the victim, the aggressor's death is the preferable consequence." Leverick, supra note 195 , at 45 .

197270 F.3d 111 (2d Cir. 2001). 
old numbers runner, fatally shot the victim, known as "Bubblegum," a 435pound man six feet tall who had previously robbed Davis three times at gunpoint, had recently raped him, and had threatened to kill Davis when he saw him next. ${ }^{198}$ On the occasion of the homicide, Davis "came out of a grocery store on the southwest corner of 146th Street and Amsterdam Avenue. As he talked there with a friend, he saw Bubblegum .... Davis was frightened. He went around the corner to get a gun for his protection."199 Davis returned to the street and there was a confrontation; Davis shot Bubblegum in the back and killed him. ${ }^{200}$ The trial court refused to instruct the jury on a justification defense, on the ground that Davis had an affirmative obligation to avoid an encounter with Bubblegum. ${ }^{201}$ "[I]nstead of going away from ... where he knows the danger is ... he walked towards Amsterdam Avenue .... [W] hen he gets to Amsterdam Avenue and 146th Street he sees the deceased a block away on 147 th street $[\mathrm{sic}] \ldots[\mathrm{H}] \mathrm{e}$ did not walk back to where he knew was a safe avenue."202 The state appellate court held that, because New York law imposed a duty to retreat, Davis's return (with a gun) to a place where he might face a risk violated his obligation to retreat. ${ }^{203}$ In overturning the conviction on federal habeas, the author of the appellate opinion recognized the critical importance of Davis's dignitary interest:

The evidence showed that the 146th Street and Amsterdam neighborhood was the center of Davis's life. That was where he earned his living as a numbers runner. That, it appeared, was his social center. The evidence shows it was also the place where the vicious Bubblegum hung out. If the law required Davis to retreat whenever Bubblegum was present on the block-as opposed to only when he faced an imminent threat of violenceDavis would be forced to leave the social and business center of his life on pain of forfeiting the legal right to defend himself against a deadly attack by a repeat tormentor. The law would essentially give over ascendancy to the bullies of the world.

For the situation Davis faced was not momentary. Had Davis left that evening on seeing Bubblegum, he would presumably have seen Bubblegum again on his return the next day, or the day after, and the same choice whether to leave on the chance that Bubblegum might attack him would present itself. The trial court's interpretation would ultimately mean that victims of threats of violence must either give up their habitat or lose their

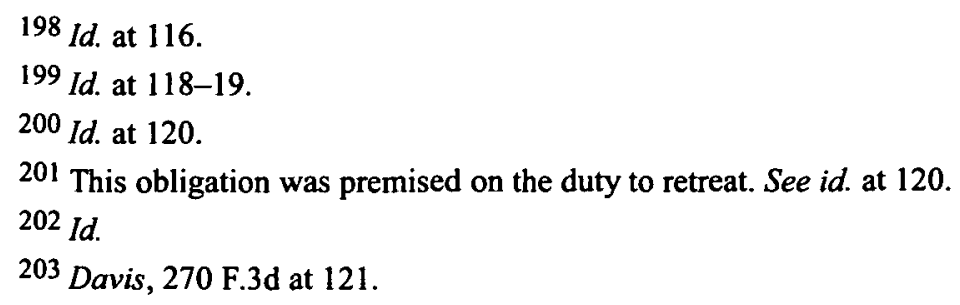


right to self defense. That is not the law of New York. Davis was not obligated to withdraw from the place where he made his life, on pain of losing his right of self defense, merely because a tormentor who had threatened to kill him was also to be found on the same streets. ${ }^{204}$

This encroachment on the dignitary interest might be justified if the victims of this type of subordination had an alternative remedy through law enforcement. As the next section shows, this seems unlikely.

\section{B. Law Enforcement as an Inadequate Substitute}

One theory about the legitimacy of self-defense is that the defender is acting for the state as law enforcer in those instances where the state's enforcement mechanisms are inadequately protective of individual rights. ${ }^{205}$ This explains some constraints on the doctrine, such as the requirement of imminence; self-defense is available only where the state does not provide adequate protection or is not otherwise competent to protect the individual in a timely fashion. 206

${ }^{204}$ Id. at $128 \mathrm{n} .6$. Though Judge Leval wrote this opinion for a three-judge panel, he noted that in making these comments in particular, he was "speaking for himself alone." Id.

205 See, e.g., Kremnitzer \& Ghanayim, supra note 192, at 899:

[S]elf-defense is intended to preserve the legal order by granting every person the right to fend off unlawful attacks. Protecting the legal order is, first and foremost, the role of the state, by means of its law enforcement agencies. This derives from the state's absolute monopoly over the use of force. The right to employ force under conditions of self-defense is a right that is derived from the state's right and duty to preserve the legal order. It is an exception to the prohibition upon the use of force by individuals. A person acting in self-defense is a 'substitute policeman.'

206 Fletcher, supra note 187 , at 570:

[W] hen an attack against private individuals is imminent, the police are no longer in a position to intervene and exercise the state's function of securing public safety. The individual right to self-defense kicks in precisely because immediate action is necessary. Individuals do not cede a total monopoly of force to the state. They reserve the right when danger is imminent and otherwise unavoidable to secure their own safety against aggression.

See also Fletcher, supra note 64, at 867 , describing Blackstone's view:

The function of the law is to provide redress for the violation of rights, but not to protect and approve the vindication of rights jeopardized by the aggression of others. According to this view of necessary defense, the private use of force is tolerated only because the state fails in its task of providing protection against aggression. If the privilege of necessary defense is derivative of the state's monopoly of force, then the regulation of the defense invariably reflects the interest both of the aggressor and the defender. If the latter can save the life of the former by retreating from the 
Scholars have questioned whether, "where there is a gap between the theory of state protection and the reality of police indifference," 207 we should recognize a different and perhaps broader right of self-defense. ${ }^{208}$ Expanding the frame to deprive an actor of a self-defense claim if he fails to yield to encroachments on his dignitary interest is not reasonable if law enforcement is unlikely to provide a solution to the problem. Diffuse threats of future violence and intimidation may present situations which law enforcement does not address very effectively. Moreover, the victims of such threats may hesitate to involve police. In the Davis case, for example, Davis did not report Bubblegum's violent assaults to the police: "[h]e believed the police would be unsympathetic to a numbers runner and would do little to protect him. Also, Davis feared that if he reported the incidents Bubblegum would retaliate." 209

A broad framing rule might make sense if the goal were to prevent vigilantism in an environment with a vigorous and responsive law enforcement presence. Supporters of the Model Penal Code rule, requiring an actor to submit to an order to refrain from doing something or forego his right of self-defense, ${ }^{210}$ suggest precisely this. Prof. Robinson argues that the Model Penal Code rule is mitigated "by the fact that [defendant's] freedom of movement may be restricted only until he notifies the authorities of [the aggressor's] threat." 211 This assumes that upon being informed of such a threat, the police would move with alacrity to protect the dignitary interests of the actor reporting such intimidation. The context of the cases discussed in this article makes clear the fallacy inherent in this notion. Mob violence, like that at issue in Laney, or individual intimidation, like that in Davis, seem singularly unsusceptible to effective law enforcement control. ${ }^{212}$ There is no

conflict, the greater social good requires him to withdraw. Blackstone's view of the state as the vindicator of our rights leads us to the denial of personal autonomy as a relevant premise in the theory of self-defense.

207 Fletcher, supra note 187 , at 571.

208 Id.

${ }^{209}$ Davis, 270 F.3d at 117.

210 The Model Penal Code rule is discussed supra notes 167-74 and accompanying text.

211 Robinson, supra note 72 , at 87 . Robinson goes on to recognize that the assumption that "authorities will take the matter seriously and will be able to resolve it" might be incorrect. Id.

212 The riots at issue in Laney were plainly beyond the control of law enforcement. In the words of the Washington Post: "Blazing race hatred turned the streets of Washington into battlefields last night. Surging mobs of blacks and whites proved themselves stronger than the law in the nation's capital." CHALMERS M. ROBERTS, THE WASHINGTON POST: THE FIRST 100 YEARS 152 (Houghton Mifflin 1977). 
little irony in limiting individuals' access to self-defense most aggressively in circumstances in which reliance on law enforcement is least likely to help them.

Up until this point, this Article has not focused on the elephant in the room and the subject of vast quantities of recent scholarship: the issue of assertions of self-defense by victims of domestic violence. An advocate of domestic violence victims might contend that broad frames benefit such defendants, by contextualizing the violent environment in which they found themselves, and that a narrow frame would accordingly disadvantage them. I have two responses to such arguments. The first is that a broad frame is not invariably beneficial to a domestic violence victim claiming self-defense. In some situations, framing could be a technique by which victims of domestic violence might be deprived of the privilege of lethal force in self-defense. If, for example, the jury in such a case were instructed that the victim had a duty to avoid the situation, a factfinder might deprive her of the defense if she could have left the home but did not. ${ }^{213}$ Using an expanded frame to deprive such an actor of a claim of self-defense would encroach on the dignitary interest of such a victim. The second response is that the dignitary interest requires only that an individual not be deprived of a self-defense claim based on choices or decisions within the expanded frame. Some asymmetry might be legitimate, however. It might be appropriate to consider evidence of earlier events or decisions to contextualize a self-defense claim, as long as that evidence was not used to preclude the claim.

\section{Asymmetry Between Conduct and Result}

The conclusion that the expanded frame permits the factfinder to consider earlier conduct by the defendant to determine whether the defendant could have avoided the encounter may result in a finding of no necessity and an absolute bar to a claim of self-defense. In that sense, the framing decision is outcome-determinative. The actor whose conduct is deemed unnecessary

213 Arthur Ripstein, Self-Defense and Equal Protection, 57 U. PITr. L. REV. 685, 702 (1996):

Any explanation we might give of her failure to leave the relationship earlier is not to the point - at the moment of choice, she had only two options. Some of the factors that limited her ability to leave the relationship earlier continue to be relevant, including the likelihood of later attacks. But other factors, such as her fear of social stigma, however significant they may be to her earlier failure to leave, are not sufficient to establish that she had no choice but to kill or be killed. Understanding those fears explains how she could have stayed in a situation that led to her moment of decision, but the justification for taking her abuser's life depends on her alternatives at the last moment. 
by virtue of the framing choice has no justification claim. This is true even though there is ordinarily no analysis of the culpability. accompanying the earlier decision.

Permitting an expanded frame to deprive a defendant of a claim of selfdefense accordingly can result in a disproportionate penalty for the actor's conduct. The loss of the self-defense privilege can be based on decisions to engage in lawful conduct with an uncertain and unanalyzed culpability. In a situation where lethal self-defense is at issue, the choice to walk down a particular street or to open the door to what might otherwise have been an avoidable conflict can result in a conviction for murder. ${ }^{214}$

Prof. Paul Robinson identified this problem-in a categorical sense-in his article, Causing the Conditions of One's Own Defense: A Study in the Limits of Theory in Criminal Law Doctrine. ${ }^{215}$ The article discussed a range of doctrines which deny an actor a defense when the actor played some role in creating the situation that led to the ultimate criminal act, and recognized that these doctrines deprive an actor of recourse to a defense without considering that actor's culpability. 216 Prof. Robinson's suggested solution was to expand the time frame, rather than to contract it, and to look to the actor's conduct and culpability at the time of the creation of the initial condition, rather than at the time of the ultimate justified or excused criminal act, as the basis for imposing criminal liability. ${ }^{217}$

The first half of Prof. Robinson's argument-that using prior conduct as a basis for completely depriving an actor of what would otherwise be a valid defense is inappropriate-is consistent with the analysis here. His second suggestion - that liability should instead be imposed based on the actor's earlier conduct, as long as it was accompanied by the appropriate mental state-is uncontroversial in theory, though more problematic in application

\footnotetext{
214 Prof. Paul Robinson recognized this problem:

The "at fault" provisions, even at best, are defective because they are oversimplified. Although apparently based on principles of fault and blameworthiness, these provisions actually avoid the relevant inquiry-the actor's culpability as to committing the offense-and instead rely on rough-and-ready rules that only roughly approximate the results dictated by the culpability principle.
}

Paul Robinson, Causing the Conditions of One's Own Defense: A Study in the Limits of Theory in Criminal Law Doctrine, 71 VA. L. REV. 1, 13 (1985). Another concern is the relative culpability of the victim and the defendant and whether the victim's conduct should be considered in determining the liability of the perpetrator. For an extensive discussion of the issue, see generally VERA BERGELSON, VICTIMS' RIGHTS AND VICTIMS' WRONGS: COMPARATTVE LIABILITY IN CRIMINAL LAW (2009).
215 Id.
216 Id. at $10-14$.
217 Id. at 27-38. 
than his analysis recognizes. Prof. Robinson argues that if $\mathrm{X}$ engages in conduct - even lawful conduct-with the intent that it will move another person, $Y$, to assault him unlawfully and entitle him to use lethal force against $Y$, then $X$ should be guilty of murder if he incites $Y, Y$ responds as predicted, and $X$ kills $Y$ in what would otherwise be justifiable self-defense.

This is not a convincing solution, for a number of reasons. First, as a practical matter, proof of such elaborate intent as the basis for a murder conviction seems more likely to be the basis of a Law \& Order subplot than an actual homicide case. ${ }^{218}$ Second, and more critical, is the problem of causation. If $X$ taunts $Y$, and $Y$ responds with unlawful violence, at which point $X$ kills $Y$ in self-defense, Prof. Robinson would say that $X$ 's initial taunt should be the basis for imposing criminal liability on $X$, assuming that $\mathrm{X}$ knew that $\mathrm{Y}$ would respond with lethal force to his taunts. It is at least possible, however, that Y's unlawful and homicidal act is a supervening cause of his own death. It may have been foreseeable that he would act unlawfully, but his decision is an act of "free, deliberate and informed" human intervention which can break the causal chain. ${ }^{219}$

More significant, for the purposes of this article, Prof. Robinson fails to recognize the dignitary interest. If $X$ knows that $Y$ will assault him if he goes to the grocery store, yet $X$ goes to the grocery store, Prof. Robinson would view this as an appropriate instance for imposing criminal liability on $\mathrm{X}$ based on his decision to go to the store (assuming the anticipated lethal encounter ensues and $X$ kills $Y$ in self-defense).

We could instead analogize the actor deprived of his self-defense claim based on his prior conduct to the initial aggressor, who is not privileged to rely on self-defense notwithstanding the fact that he faces, at the time he acts, an imminent and unlawful threat of lethal force. Initial aggression is an "onoff" switch; absent affirmative withdrawal from the encounter, an actor's status as an initial aggressor entirely precludes relying on a claim of selfdefense. ${ }^{220}$

218 Prof. Robinson recognizes the proof problems inherent in such an approach, and proposes a range of presumptions, of admittedly dubious constitutionality, to solve the prosecution's problem. $1 d$. at 58-60.

219 DRESSLER, supra note $23, \S 14.03[\mathrm{C}][6]$. The problem is exacerbated because the statute Prof. Robinson proposed uses the phrase "causes the circumstances that justify his ... engaging in the conduct that constitutes the offense," leaving a factfinder to parse out what "causes the circumstances" means and to distinguish that from the legal concept of proximate causation. Robinson, supra note 214, at 50.

${ }^{220}$ Fletcher, supra note 64 , at 858 :

The factor that skews the balancing in favor of the defender is the aggressor's culpability in starting the fight. As the party morally at fault for threatening the defender's interests, the aggressor is entitled to lesser consideration in the balancing process. His interests are discounted, as it were, by the degree of his culpability. The 
As a theoretical matter, how should we understand the loss of the privilege of self-defense to an initial aggressor? One theory is that the initial aggressor is an unlawful actor; the response of the victim to that unlawful aggression is therefore lawful, and the initial aggressor has no right to use self-defense to resist lawful force. ${ }^{221}$ In that sense, the interaction is a transfer of the privilege of self-defense from one to the other. The unlawful behavior of the initial aggressor creates a situation in which the victim is privileged to respond in self-defense, but the aggressor is not. If the victim responds disproportionately - as by responding with lethal force to a nonlethal threat-he becomes the unlawful actor. The victim's use of force would then be unjustified.222 One article refers to this as the "innocents preferred" principle, which provides that, in an encounter, only a nonaggressor is privileged to violate the underlying "core principle" that "killing is bad." 223 Even though necessity might subsequently justify his acting in self-defense, the initial aggressor must disavow his status as wrongdoer to regain the privilege.

It is unfair to treat our expanded-frame defendants as analogous to initial aggressors for several reasons. First, the initial aggressor engages in unlawful behavior. That triggering decision to engage in illegality is the wrong that denies the actor the right of self-defense. In the context of framing, however,

extent to which his life is discounted determines whether the defender may use deadly force to defend against rape, serious bodily harm, loss of irreplaceable property and even, possibly, the loss of less important interests. The underlying premise is that if someone culpably endangers the interests of another, his interests are less worthy of protection.

${ }^{221}$ See, e.g., LAFAVE, supra note 22, § 10.4(e) (footnotes omitted):

It is generally said that one who is the aggressor in an encounter with another-i.e., one who brings about the difficulty with the other-may not avail himself of the defense of self-defense. Ordinarily, this is certainly a correct statement, since the aggressor's victim, defending himself against the aggressor, is using lawful, not unlawful, force; and the force defended against must be unlawful force, for selfdefense.

The exception is the case in which "both parties are in the wrong," PERKINS \& BOYCE, supra note 48 , at 1129 , in which neither party is privileged to use deadly force in selfdefense. Mutual combat is the most common such situation. Id. at 1129 n.92.

222 Another approach suggests discounting - that "by acting as an initial aggressor, the actor devalues his life relative to that of the defendant." Leverick, supra note 195, at 46.

${ }^{223}$ David McCord \& Sandra K. Lyons, Moral Reasoning and the Criminal Law: The Example of Self-Defense, 30 AM. CRIM. L. REV. 97, 132 (1992). This theory, McCord and Lyons argue, is supported by Aquinian moral theory, which provided that "an innocent, who is not violating God's will, is in a superior moral position to an aggressor, who is violating God's will. Thus, the innocent who is attacked can legitimately act to save his own life." Id. at 132. 
the conduct that can deprive an actor of the privilege of self-defense may be entirely lawful. Treating the failure-to-avoid actor as the equivalent of an initial aggressor fails to recognize that choices inside the broad frame may be significantly more ambiguous. "[T]he correct moral answers are not transparently obvious. ... [T] here are conflicts between the moral claims of the alleged wrongdoer and those of the alleged victim."224

Second, as Prof. Waldron has noted, initial aggressors are different because they pose an ongoing threat to the safety of others:

[T] he real reason for preferring the safety of the innocent to that of the aggressor is the continued threat that aggressors usually pose. In most circumstances, the survival of the guilty amounts to a threat not only to the particular innocent person whom he confronts, but also to other innocent people in the future. ... It follows that the victim of an attack, who fights back in self defense, is acting on account of all who might be threatened in the future, rather than simply for himself. 225

In view of these differences, perhaps the better analogy in the broad framing situation would be the doctrine of imperfect self-defense. A defendant who honestly but unreasonably believes that she faces an imminent threat of unlawful lethal force, and who responds, in turn, with deadly force, has been negligent. She failed to perceive the facts as they actually were, when a reasonable person in her situation would have done so. Should this deprive her entirely of the claim of self-defense? Some jurisdictions recognize a partial defense for such actors. They are not fully exonerated, because their belief in the need for the use of lethal force was unreasonably held. They are not fully culpable, either, because they genuinely believed they needed to use lethal force to save their own lives. Instead, these jurisdictions provide a partial mitigation defense in such a situation, reducing what would otherwise be murder to manslaughter. ${ }^{226}$ The Model Penal Code treats the actor claiming self-defense whose belief in the need for the use of force is negligently or recklessly held as having no defense to a reckless or negligent crime. 227

224 Id. at 100.

225 Jeremy Waldron, Self-Defense: Agent-Neutral and Agent-Relative Accounts, 88 CAL. L. REV. 711, 735 (2000).

226 DRESSLER, supra note $23, \S 18.03$. Prof. Dressler criticizes the denomination of this mitigation as "imperfect self-defense," since it is inherently contradictory to deem an act self-defense, yet punish it. Id.; see also LAFAVE, supra note 22, § 10.4(i).

227 MODEL PENAL CODE $§ 3.09(2)$. Dressler's view is that this is "sensible," because:

[T] he traditional common law rule, which does not recognize an imperfect defense, authorizes $D$ 's conviction for a more serious offense than his overall culpability-he may be convicted of a crime of intent, although he is really a negligent or reckless 
If lawful acts taken within the broader frame are to be considered at all in assessing the defendant's criminal responsibility, they should only be held to diminish, not to deny, a claim of self-defense. In such a situation, the failure to avoid the situation, rather than creating an absolute bar to a justification defense, might establish a lesser degree of culpability. ${ }^{228}$ Requiring such culpability would impose some limits on the degree of encroachment on the dignitary interest permitted by broad drawing of the frame.

\section{CONCLUSION}

This Article has shown that the law regarding the framing of self-defense cases is fundamentally chaotic. Instructions permit and decisions conclude, variously, either that a person may be deprived of the privilege of selfdefense by going to the wrong place at the wrong time or that she may not. The law should provide a clearer answer to whether the self-defense problem should be framed to deny the actor the privilege of self-defense based on earlier choices that might be viewed as "looking for trouble."

The Article argues not just that the rule on framing should be clear, but that the question should not be framed to deny an actor the privilege of selfdefense based on a decision to go somewhere or do something lawful that the actor had a right to do. To bar the claim of self-defense under those circumstances would be to privilege the wrongful actor, to permit the bully to rule the streets, and to permit a fundamental encroachment on the dignitary interests of innocent actors. If we understand an invasion of the dignitary interest as a problem of subordination and subjugation, it is easier to understand why the answer that preserves life is not necessarily always the optimal choice. The law of self-defense should take more reliable account of the dignitary interest, and recognize the framing difficulties that implicate it. Instructions that more clearly constrain the power of factfinders to consider a broad frame in assessing whether the exercise of self-defense was "necessary" or "reasonable" or in some other context ultimately protect the interest, not simply in doing what one pleases, but in preventing the subjugation of one person at the unlawful hands of another. Law enforcement may not be very effective at addressing ambiguous threats of future harm or intimidation, making loss of the self-defense claim under these circumstances

wrongdoer. ... The Code approach permits conviction of an offense in accord with the culpability of his mistake.

DRESSLER, supra note $23, \S 18.06[\mathrm{~B}]$.

228 See Robinson, supra note 214 , at 10 ("' $[\mathrm{A}] \mathrm{n}$ approach that excludes a defense because the actor was at fault in causing the defense" is problematic because "such an approach does not distinguish among different levels of fault in causing the conditions of the defense."). 
particularly problematic. Ultimately, depriving the actor of a self-defense claim under these circumstances makes the actor responsible for a justifiable act of violence based solely on an earlier decision not to avoid a confrontational situation with an unlawful aggressor. The actor's culpability in such a situation may be unclear and should not be the basis to deny the claim of self-defense to an otherwise justified actor.

Critics may suggest that this Article permits lethal force to be used in response to petty encroachments on dignity and autonomy. ${ }^{229}$ In fact, it does nothing of the kind. The Article does not argue that the actor who is threatened or commanded to behave (or avoid behaving) in a certain way, may respond to that encroachment on his autonomy with lethal force. It argues only that those threats or commands by an unlawful actor should not constrain the dignitary freedoms of the threatened person. The conduct of the actor who goes to the place where a dangerous encounter may ensue is not a prohibited "preemptive strike," 230 in which the person fearing an attack acts first, deciding "it is wiser to strike first than to wait until the actual aggression." 231 Nor is the actor using lethal force to prevent minor intrusions to autonomy. The question in the framing cases is not "whether a history of abuse and domination justifies retaliatory action by the subordinated party."232 It does not. The issue therefore is not, "If the local bully threatens to harm you if you go to the grocery store, may you shoot him?" Instead, it is simply whether you may go to the grocery store, bringing with you your privilege to engage in self-defense. The answer to that question should unquestionably be yes.

229 Fletcher, supra note 187 , at 560 (instances of petty theft or inappropriate touching probably would not justify the use of lethal force; a woman "may kill to ward off a threat to her sexual autonomy, but she has no license to take life in order to avoid every petty interference with her autonomy").

$230 \mathrm{Id}$. at $556-57$.

231 Id. at 557.

232 Id. at 576. 
